\title{
Unraveling the hidden paleobiodiversity of the Middle Devonian (Emsian) crinoids (Crinoidea, Echinodermata) from Poland
}

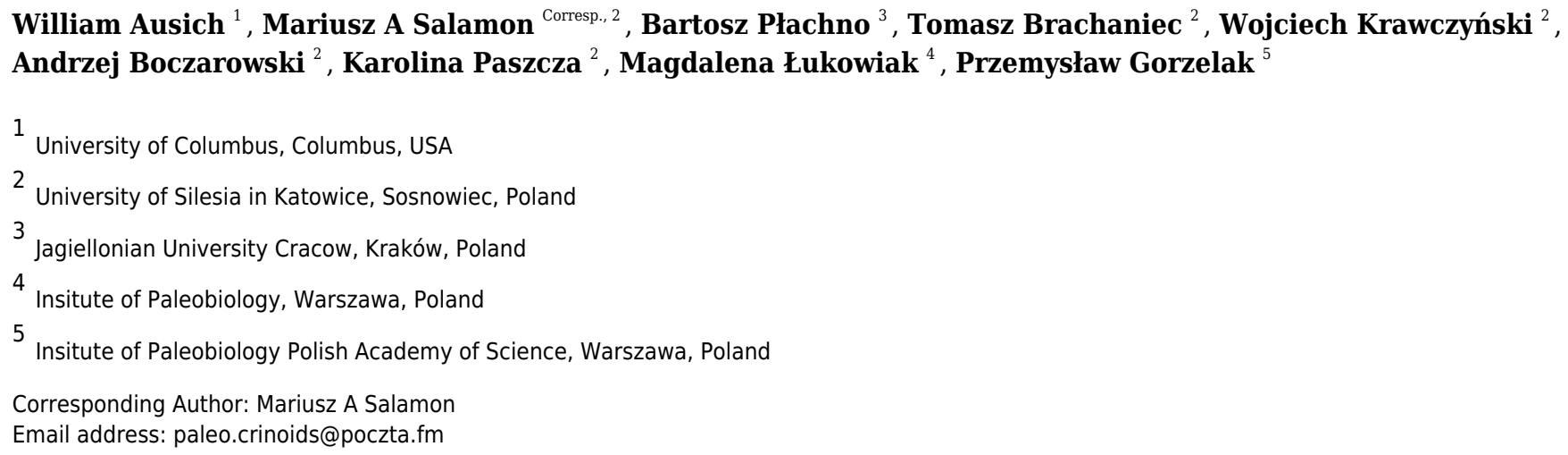

Most previous publications on Devonian crinoids from the Holy Cross Mountains in Poland have concentrated on crinoid columns, and until now, little has been published about crinoid cups and calyxes. Herein, five crinoid taxa are described from an abundant occurrence of aboral cups and partial crowns from the Bukowa Góra Member (Emsian) in the Holy Cross Mountains of southern Poland. The following taxa are described:

Bactrocrinites sp., Codiacrinus sevastopuloi sp. nov., Halocrinites geminatus (Bohatý, 2005), Halocrinites schlotheimii Steininger, 1831, and a single brachial plate from a flexible crinoid placed in Flexibilia incertae sedis. Simple discoid holdfasts are also present encrusted to cylindrical stromatoporoids. These taxa are the first crinoids described from the remains of partial crowns from Emsian strata of Poland. 
1 Unraveling the hidden paleobiodiversity of the Middle Devonian (Emsian) crinoids

2 (Crinoidea, Echinodermata) from Poland

3

4 William I. Ausich ${ }^{1}$, Mariusz A. Salamon²*, Bartosz J. Płachno ${ }^{3}$, Tomasz Brachaniec ${ }^{2}$, Wojciech

5 Krawczyński², Andrzej Boczarowski² ${ }^{2}$ Karolina Paszcza ${ }^{2}$, Magdalena Łukowiak ${ }^{4}$ and

6 Przemysław Gorzelak ${ }^{4}$

7

$8{ }^{1}$ School of Earth Sciences, Ohio State University, 125 South Oval Mall, Columbus, Ohio, U.S.A.

$9{ }^{2 *}$ University of Silesia in Katowice, Faculty of Natural Sciences, Institute of Earth Sciences,

10 Będzińska Street 60, 41-200 Sosnowiec, Poland, e-mail: paleo.crinoids@poczta.fm

11 Jagiellonian University in Kraków, Faculty of Biology, Institute of Botany, Gronostajowa Street

12 9, 30-387 Cracow, Poland

${ }^{4}$ Institute of Paleobiology, Polish Academy of Sciences, Twarda 51/55, 00-818 Warsaw, Poland

Corresponding Author:

Mariusz A. Salamon ${ }^{2}$

${ }^{2}$ University of Silesia in Katowice, Faculty of Natural Sciences, Institute of Earth Sciences,

Będzińska Street 60, 41-200 Sosnowiec, Poland

e-mail: paleo.crinoids@poczta.fm 


\section{ABSTRACT}

23 Most previous publications on Devonian crinoids from the Holy Cross Mountains in Poland have concentrated on crinoid columns, and until now, little has been published about crinoid cups and calyxes. Herein, five crinoid taxa are described from an abundant occurrence of aboral cups and partial crowns from the Bukowa Góra Member (Emsian) in the Holy Cross Mountains of southern Poland. The following taxa are described: Bactrocrinites sp., Codiacrinus sevastopuloi sp. nov., Halocrinites geminatus (Bohatý, 2005), Halocrinites schlotheimii Steininger, 1831, and a single brachial plate from a flexible crinoid placed in Flexibilia incertae sedis. Simple discoid holdfasts are also present encrusted to cylindrical stromatoporoids. These taxa are the first crinoids described from the remains of partial crowns from Emsian strata of Poland.

Subjects Paleontology

Keywords Devonian, Emsian, Poland, crinoids, Echinodermata, paleobiodiversity, Holy Cross Mountains.

\section{INTRODUCTION}

Crinoid remains are abundant in Devonian (Emsian-Famennian) strata of Poland (Holy Cross Mountains, southern Poland; Cracow-Silesian area, southern Poland; Sudetes, southwestern Poland; Pomerania, northern Poland). Polish Devonian crinoids were mentioned initially by 
42 Dames (1868), Zeuschner (1867, 1869), Gürich (1896), and Sobolev (1909). Much later, Kongiel

43 (1958) and Piotrowski (1977) described the occurrence of the genus Ammonicrinus in the Holy

44 Cross Mountains (see also Gorzelak et al., 2014; Bohatý, 2011). In a series of subsequent papers,

45 Głuchowski (1980, 1981a-c, 1993a-b, 2002, 2003; see also Hauser, 2002), Bohatý, 2005, 2009a,

46 2011) listed $~ 50$ crinoid taxa from Devonian (Lochkovian, Emsian-Famennian) strata of Poland

47 (for summary see Fig. 1). With the exception of taxa listed below, most of them were based on

48 isolated skeletal remains, mainly columnals; and they were described using the principles of

49 artificial classification of crinoid remains proposed by Moore and Jeffords (1968). Głuchowski

50 (2003) added that the applicability of crinoid stems may be useful for stratigraphic and

51 correlation purposes.

52 To date, only nine crinoid taxa have been identified on the basis of complete (or nearly

53 complete) crowns and aboral cups with column from the Devonian of Poland. Among these is

54 Haplocrinites sp. from Givetian-Frasnian of Holy Cross Mountains recorded by Głuchowski

55 (1993a, 2003). Specimens of this taxon from late Frasnian Detrital Beds of the Holy Cross

56 Mountains were later designated by Hauser (2002) as Haplocrinites gluchowskii Hauser, 2002.

57 According to Głuchowski et al. (2006) Givetian and early Frasnian Haplocrinites sp. specimens

58 differ from $H$. gluchowskii in having distinctly less prominent radial facets. Another haplocrinitid

59 (Haplocrinitidae) species is Haplocrinites aremoricensis Le Menn, 1985 from the uppermost

60 Givetian of the Holy Cross Mountains (Głuchowski, 1993a). Platyhexacrinus? was identified by

61 Głuchowski (1993a) (see Bohatý, 2009a).Also four cupressocrinitid (Cupressocrinitidae) taxa

62 have been described from the Holy Cross Mountains by Głuchowski (1993a). These are

63 Cupressocrinites cf. abbreviatus Goldfuss (late Eifelian-late Givetian) (now Halocrinites

64 schlotheimii Steininger, 1831), H. geminatus Bohatý, 2005 (these specimens were originally 
65 described as Cupressocrinites cf. abbreviatus in Głuchowski, 1993a, fig. 6g-h); C. inflatus

66 Schultze, 1866 (late Givetian) (now Halocrinites inflatus), and C. sampelayoi (Almela and

67 Revilla, 1950) (now Halocrinites minor (Schultze, 1866) known from late Givetian (Głuchowski

68 1993a, 2002). The remaining two crinoid species belong to the Melocrinitidae. These are

69

Melocrinites cf. gibbosus Goldfuss, 1831 and M. cf. hieroglyphicus Goldfuss, 1831, which were found in the sediments of the uppermost Frasnian.

Only four crinoid taxa are known from the Emsian of the Holy Cross Mountains and all were documented on the basis of isolated columnals or their impressions (casts). In particular, Głuchowski (1981b, 2002) listed the following taxa from the Bukowa Góra shales: Acanthocrinus sp. (col.), Formosocrinus cf. formosus (col.) (Yeltyscheva and Sisova, 1973), Laudonomphalus humilicarinatus (col.) (Yeltyscheva in Yeltyscheva and Dubatolova, 1961) [now Hexacrinites? humilicarinatus (col.) (note that an affiliation with the crown-based genus, Hexacrinites, cannot be verified.)], and Marettocrinus subbiconcavus (col.) (Stukalina, 1965).

Here we report complete or almost complete Emsian cups associated with numerous isolated calyx and column remains from the Bukowa Góra Member in the Holy Cross Mountains of southern Poland. These include Bactrocrinites sp., Codiacrinus sevastopuloi sp. nov., Halocrinites geminatus (Bohatý, 2005), Halocrinites schlotheimii Steininger, 1831, and Flexibilia incertae sedis. Simple discoid holdfasts are also present. Remains of unidentifiable specimens indicate that several other crinoids also existed in the Bukowa Góra Member fauna.

Figure 1 around here 


\section{GEOLOGIC FRAMEWORK}

89 The Holy Cross Mountains are located in the southern part of Poland. Their main element is the

90 Paleozoic core, divided into two parts: the Łysogóry region (northern, connected with the

91 Łysogóry Block) and the Kielce region (southern, connected with the Małopolska Block; see Fig.

92 2A). These regions differ from each other by facies development of contemporaneous deposits.

93 Devonian sediments of the Łysogóry region were formed in the deeper basin in contrast to the

94 shallower facies exposed in the Kielce region (Szulczewski, 1995).

95
Outcrops of Lower Devonian rocks in the Łysogóry Region are connected with the southern limb of the Bodzentyn Syncline. The sedimentary rocks of the upper Emsian are best exposed in the active quarry "Bukowa Góra", located about 16 km northeast of Kielce (see Fig. 2A). The section includes sediments belonging to patulus Conodont Zone and douglastownenseeurypterota Miospore Zone (Malec, 2005; Filipiak, 2011; Fijałkowska-Madej \& Malec, 2011).

In the lower part of the section, the 110 m thick Zagórze "formation" comprised of siliciclastic deposits is present (see Fig. 2B). They are mostly represented by quartzitic sandstones with abundant trace fossils and by claystones. Within sandstones, there are storm originated brachiopod coquinas with gastropods, bivalves, tentaculitids, crinoids, rarely trilobites, rugose corals, nautiloids, and ostracodes. At the top of the Zagórze "formation", conglomerates and sandstones of estuary facies crop out. Deposits of the Zagórze "formation" were formed in the shallow sea environment from the lagoon to the shoreface (Szulczewski \& Porębski, 2008; see also Łobanowski, 1971, 1981). 
As a result of the progressive deepening of the marine basin, deposits of the

109 Grzegorzowice Formation were formed, which is also present in the Kielce region (Malec, 2005;

110 Wójcik, 2015). In the Bukowa Góra quarry section the two members are present: the Bukowa

111 Góra Member and the Kapkazy Member. The Bukowa Góra Member occurs only within the

112 patulus Conodont Zone in the western part of the Bodzentyn Syncline (see Fig. 2B). In the

113 eastern part of the Bodzentyn Syncline, the Bukowa Góra Member appears earlier, i.e., in the

114 serotinus Conodont Zone (Malec, 2005). Malec (2005) marked the lower boundary of the

115 Bukowa Góra Member in the bottom of the complex of dark claystones, whereas Szulczewski \&

116 Porębski (2008) put this boundary on the pebble conglomerate that begins of the lower shoreface

117 to offshore transitional series.

In the lower part of interbedded sandstones, the Bukowa Góra Member is comprised of sandstones, siltstones, and claystones, which are about $7 \mathrm{~m}$ thick (see Szulczewski \& Porębski, 2008). Above them appears the offshore facies represented by black to dark-gray claystones and silty claystones with a thickness of $\sim 13 \mathrm{~m}$ and containing discontinuous beds of dolomitic

122 limestones up to $10 \mathrm{~cm}$ thick (see Fig. 2B). Both claystones and limestones contain a rich faunal assemblage related to the colonization of the soft sea bottom. There are massive colonies of both stromatoporoids and tabulate corals accompanied by solitary rugoses, brachiopods, crinoids, ostracods, gastropods and trilobites (Malec, 2005; see also Głuchowski, 1993b; FijałkowskaMader et al., 1997). Member, which is $\sim 34 \mathrm{~m}$ thick. The lower part of the Kapkazy Member is comprised of coarsegrained and conglomeratic sandstones, containing rare crinoids, brachiopods and gastropods. 
130 Above this is fine-grained sandstone, which is indicative of a clear shallowing of the sea basin 131 (Malec 2005).

\section{MATERIALS AND METHODS}

The studied material from Bukowa Góra Quarry was collected in 2019 and 2021. The first step consisted of examination of slab surfaces in the field. At this stage, numerous crinoid remains (isolated columnals and complete or nearly complete crowns) were collected. The next step consisted of soaking the respective samples (11 shales samples weighing each ca. $10 \mathrm{~kg}$ ) only with hot water. Limy samples (4 samples weighing each ca. $5 \mathrm{~kg}$ ) were soaked with Glauber's salt. These samples were then boiled and frozen (2-3 times). The residues were finally washed with running tap water and sieved on a sieve column (Ø1.0, 0.315 and $0.1 \mathrm{~mm}$ mesh). The final step consisted of drying the shaly and limy residues at $160^{\circ} \mathrm{C}$. Residue was hand-picked from each macerated sample for microscopic study. discussed here are deposited in the University of Silesia in Katowice, Faculty of Natural

148 Sciences, Institute of Earth Sciences, Poland GIUS 4-3696) and in the Senckenberg

149 Forschungsinstitute und Naturmuseum, Frankfurt am Main, Germany (SMF). 
152 (ICZN), and hence the new names contained in the electronic version are effectively published

153 under that Code from the electronic edition alone. This published work and the nomenclatural

154 acts it contains have been registered in ZooBank, the online registration system for the ICZN.

155 The ZooBank LSIDs (Life Science Identifiers) can be resolved and the associated information

156 viewed through any standard web browser by appending the LSID to the prefix

157 http://zoobank.org/. The LSID for this publication is: zoobank.org:pub:B89FD16E-2084-431A-

158 ACE9-4E4362C6C3CD, and for taxonomic registration it is:

159 urn:lsid:zoobank.org:act:66DBF909-CF1C-479C-BDA0-F324F4FFC15F. The online version of

160 this work is archived and available from the following digital repositories: PeerJ, PubMed

161 Central SCIE and CLOCKSS".

162

163

RESULTS

164

165

More than 1,000 of columnals and pluricolumnals, dozens of disarticulated ossicles from cups and arms, and 26 complete (or nearly complete) cups/calyces were collected. As a result of our investigations, the following taxa were identified: Bactrocrinites sp., Codiacrinus sevastopuloi sp. nov., Halocrinites geminatus (Bohatý, 2005), Halocrinites schlotheimii Steininger, 1831, and Flexibilia incertae sedis. Simple discoid holdfasts are also described.

\section{SYSTEMATIC PALEONTOLOGY}

173 Abbreviations used for specimen measurements include $\mathrm{ACH}$, aboral cup height; ACdistW, 174 distal width of aboral cup; ACmaxW, maximum width of aboral cup; ACproxW, proximal width 
175 of aboral cup; BConW, basal concavity width; BH, basal plate height; BW, basal plate maximum

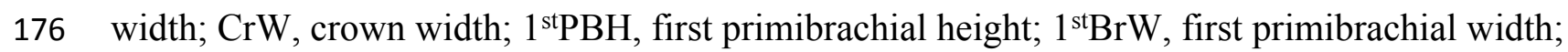

$1772^{\text {nd }} P B H$, second primibrachial height; $2^{\text {nd }} \mathrm{PBdistW}$, second primibrachial distal width; $2^{\text {nd }}$

178 PBproxW, second primibrachial distal width, $5^{\text {th }} \mathrm{PBH}$, fourth primibrachial height; $3^{\text {rd }} \mathrm{PBW}$,

179 third primibrachial width; $3^{\text {rd }} \mathrm{PBH}$, third primibrachial height; $5^{\text {th }} \mathrm{SBW}$, fifth primibrachial width.

180 All measurements are in mm. Terminology for encrusting organisms follows the

181 recommendations of Taylor and Wilson (2002).

182

Class Crinoidea Miller, 1821

184

Subclass Pentacrinoidea Jaekel, 1918

185

Infraclass Inadunata Wachsmuth and Springer, 1885

186

Parvclass Cladida Moore and Laudon, 1943

187

Magnorder Eucladida Wright, 2017

188

Superorder Cyathoformes Wright et al., 2017

189

Superfamily Codiacrinoidea Bather, 1890

190

Family Codiacrinidae Bather, 1890

191

Subfamily Codiacrininae Bather, 1890

192

Genus Codiacrinus Schultze, 1866

193

194

Type species

Peer) reviewing PDF | (2021:12:68648:1:0:NEW 3 Jan 2022) 
195 Codiacrinus granulatus Schultze, 1866

196 Included species

197 C. granulatus Schultze, 1866; C. nicolli Jell and Jell, 1999; C. ornatus (Prokop, 1973); C.

198 piriformis LeMenn, 1997; C. procerus (Prokop, 1973); P. rarus Jell and Holloway, 1983; C.

199 robustus LeMenn, 1997; C. schultzei Follman, 1887; C. secundus Jell, 1999.

200

201

Figure 3 around here

202

203

Codiacrinus sevastopuloi sp. nov.

204

Fig. 3A1-A4, 3B1-B3, 3C

205

Diagnosis

206

Aboral cup medium bowl shape; three or more radiating ridges from center of basal plates that

207

project onto radial and infrabasal plates, also very fine nodose sculpturing across calyx plates;

208

basal plates largest plates of aboral cup; radial facets $\sim 50 \%$ of distal width of radial plates

209

(arms and column characters not known).

210

Types

211 Holotype: GIUS4-3693/Codiacrinus1; paratypes: GIUS4-3693/Codiacrinus2, GIUS4-

$212 \quad 3693 /$ Codiacrinus3.

213 Occurrence 
214 Bukowa Góra Member (Emsian), Bukowa Góra quarry, Holy Cross Mountains, southern Poland.

\section{Description}

216 Aboral cup medium globe shaped (Fig. 3A4, 3B1), height to width ratio 1.0 , maximum width at

217 middle aboral cup height; three or more radiating ridges from center of basal plates that project

218 onto radial and infrabasal plates (Fig. 3A1), also very fine nodose sculpturing across calyx

219 plates. Infrabasal circlet $\sim 9 \%$ of aboral cup height, extends proximally in a short neck that is

220 truncate proximally with a shallow, circular basal concavity that occupies $\sim 75 \%$ of proximal

221 aboral cup width (Fig. 4A2, 4B2). Five pentagonal infrabasal plates, 3.8 times wider than high,

222 outer surface concave, sculpturing irregular nodose. Basal circlet $\sim 55 \%$ of aboral cup height;

223 basal plates largest plates in aboral cup, hexagonal, $\sim 1.2$ times higher than wide; sculpturing with

224 radiating ridges and nodes, ridges from near the center of the plates to ridges on adjoining

225 proximal and distal plates. Radial circlet $\sim 36 \%$ of aboral cup height; radial plates $\sim 1.2$ times

226 wider than high, pentagonal; plate sculpturing with ridges and nodes, ridges diagonal from base

227 of radial facet to like ridges on adjoining basal plates. Radial facets angustary ( $\sim 52 \%$ of radial

228 plate distal width), horseshoe shaped (Fig. 4A3, 4B3). Radial facets, arms, and column unknown.

229 Etymology

230 The species name is in recognition of the substantial contributions that George D. Sevastopulo

231 made to crinoid paleobiology, as well as paleontology and stratigraphy in general.

\section{Measurements}

233 GIUS4-3693/Codiacrinus1 (holotype): $\mathrm{ACH}, 9.8 ; \mathrm{ACmaxW}, 10.4 ; \mathrm{IH}, 1.5 ; \mathrm{IW}, 2.5 ; \mathrm{BH}, 5.4$;

234 BW, 7.6; RH, 5.2; RmaxW, 6.0, RdistW, 5.3, RFW, 3.1. GIUS4-3693/Codiacrinus2 (paratype): 
235 ACH, 11.25; ACmaxW, 11.25*; IH, 1.4; IW, 5.3; BH, 8.4; BW, 6.8; RH, 5.4; RmaxW, 6.6,

236 RdistW, 4.8, RFW, 2.5.

237 Remarks

238 One well-preserved and two poorly preserved aboral cups are assigned to Codiacrinus

239 sevastopuloi $\mathrm{sp}$. nov. Both poorly preserved specimens have their shapes distorted through

240 compaction.

241 Ten species of Codiacrinus, including C. sevastopuloi, are recognized herein. C.? weyeri

242 is excluded, and it is regarded either as an aberrant individual or a member of another genus. Of

243 these ten species, only three have arms and proximal columnals preserved (C. robustus, C.

244 schultzei, and C. secundus). Thus, species diagnoses are largely based on characters of the aboral

245 cup, which vary widely.

The most noticeable character used to differentiate species of Codiacrinus is the aboral cup shape, which may be low bowl, high cone, medium globe, high globe, or medium vase in shape. Codiacrinus granulatus, C. nicolli, C. robustus, and Codiacrinus sevastopuloi sp. nov. all have a medium globe-shaped aboral cup. Codiacrinus granulatus has a medium globe-shaped aboral cup, two poorly defined radiating ridges from the base of the radial facet onto each subjacent basal plate and perhaps some poorly developed concentric ridges, radial plates are the

252 largest plates in the aboral cup, and the radial facets occupy $\sim 50 \%$ of the distal radial plate width.

254 plates are the largest plates in the aboral cup, and the radial facets occupy $\sim 60 \%$ of the distal radial plate width. Codiacrinus robustus has a medium globe-shaped aboral cup, three radiating 
256 ridges from the basal plate center and otherwise smooth sculpturing, basal plates are the largest

257 plates in the aboral cup, and the radial facets occupy $\sim 50 \%$ of the distal radial plate width.

258 Alternatively, Codiacrinus sevastopuloi sp. nov. has a medium globe-shaped aboral cup, 259 three or more radiating ridges from center of basal plates that project onto radial and infrabasal 260 plates, also very fine nodose sculpturing across calyx plates, basal plates are the largest plates in 261 the aboral cup, and the radial facets occupy $\sim 50 \%$ of the distal radial plate width.

262

263

Figure 4 around here

264

265

266

267

Superfamily Dendrocrinacea Wachsmuth and Springer, 1886

Family Dendrocrinidae Wachsmuth and Springer, 1886

Genus Bactrocrinites Schnur in Steininger, 1849

268

269

\section{Type species}

Poteriocrinus fusiformis (Roemer, 1844).

\section{Included species}

272 Bactrocrinites birmanicus Reed, 1908; B. cyathus Schmidt, 1942; B. depressus (Schultze, 1866);

B. fieldi (Springer and Solcom, 1906); B. fusiformis (Roemer, 1844); B. jaekeli (Schmidt, 1934);

274 B. muelleri (Jaekel, 1895); B. oklahomaensis Strimple, 1952; B. onondagensis Goldring, 1954; 
275

276

277

278

279

280

281

282

283

284

285

B. penaneachensis LeMenn, 1985; B. porectus Bohatý, 2005; B. tenuis (Jaekel, 1895); B.?

trabicus (Schmidt, 1934); B. zeileri (Mueller in Zeiler and Wirtgen, 1855)

\author{
Bactrocrinites sp.
}

Fig. 3E, 4

\title{
Description
}

Relatively large aboral cup, aboral cup plates with pustulose plate sculpturing (Fig. 3E).

Infrabasal plates not known. Basal plates partially preserved, inferred to be the dominant plate circlet in aboral cup (Fig. 3E). C radial plate supported beneath by radianal plate and BC basal plate; D radial plate larger that $\mathrm{C}$ radial plate, supported beneath by $\mathrm{CD}$ an $\mathrm{DE}$ basal plates.

Radial facets large, semicircular, angustary, declivate. Two anal plates in aboral cup. Radianal presumably tetragonal, below and to the left of the $\mathrm{C}$ radial plate and supports the anal $\mathrm{X}$ plate on the upper left (Fig. 4). Anal X plate hexagonal, supported beneath by the CD basal plate and the radianal, separates and articulates with lateral sides of the $\mathrm{C}$ and $\mathrm{D}$ radial plates.

Other aspects of the aboral cup, anal sac, arms, and column are not known.

\section{Occurrence}

Bukowa Góra Member (Emsian), Bukowa Góra quarry, Holy Cross Mountains, southern Poland.

\section{Remarks}


294 Species diagnostic characters for Devonian Bactrocrinites include shape of the aboral cup, plate 295 sculpturing, relative heights of aboral cup plates, and the dimensions of the infrabasal and basal 296 plates. Unfortunately, the single specimen of Bactrocrinites from the Emsian of Poland is not 297 complete (GIUS4-3693/Bactrocrinites), so aboral cup shape, relative proportions of aboral cup 298 plates and the dimensions of the basal plates cannot be determined. The pustulose aboral cup 299 plate sculpturing and what are inferred to be prominent (high) basal plates most closely ally this 300 specimen with $B$. fusiformis. However, a more complete accounting of the morphology of this 301 Emsian specimen is required before a confident species assignment can be made.

Figure 5 and 6 around here

304

305

Superfamily Gasterocomoidea Roemer, 1854

306

Family Cupressocrinitidae Roemer, 1854

307

Subfamily Cupressocrininae Bohatý, 2006

308

Genus Halocrinites Steininger, 1831

309

310

Type species

311

Halocrinites schlotheimi schlotheimi Steininger, 1831. 
313 Halocrinites altus (Schultze, 1866); H. assimilis (Dubatolova, 1964); H. geminatus (Bohatý,

314 2005); H. gibber (Bather, 1919); H. heinorum Bohatý and Ausich (2021); H. inflatus inflatus

315 (Schultze, 1866); H. inflatus convexus (Hauser, 2001); H. inflatus cuneatus Bohatý, 2006; H.

316 inflatus depressus (Hauser, 2001); H. minor (Schultze, 1866); H. nodosus (Sandberger and

317 Sandberger, 1856); H. rectangularis (Schmidt, 1941); H. schlotheimii schlotheimii Steininger,

318 1831; H. schlotheimii granulosus Schultze, 1866; H. schreueri Bohatý, 2006; H. tesserula

319 (Goldfuss, 1831); H. townsendi (König, 1825); and H. urogali Roemer, 1850.

\section{Remarks}

321 As discussed in Bohatý and Ausich (2021), generic and specific assignments of the

322 Cupressocrinitidae have been varied, commonly changed, and confused until recently (e.g.,

Bohatý, 2005; Bohatý, 2006; Bohatý, 2009b; Bohatý and Herbig, 2010; and Bohatý and Ausich, 2021). Two species of Halocrinites are recognized from the Bukowa Góra Member in Poland, including H. geminatus (Bohatý, 2005) and H. schlotheimii (Steininger, 1831). Most

Halocrinites specimens from Poland are lacking the exoplacoid layer or are sufficiently worn

327 that the character of the exoplacoid layer cannot be determined. One exception is specimen

GIUS 4-3696Hscholth6 (Fig. 5E), although even this specimen is worn. They are differentiated on the basis of aboral cup shape, basal plate morphology, size of the infrabasal circlet relative to the size of the proximalmost columnal, and the size of the basal concavity, as described below. Halocrinites schlotheimii has a bowl-shaped aboral cup with a ratio of aboral cup diameter versus crown height $\sim 1: 1.15-2.0$; aboral cup typically $\sim 2.0$ times wider than high; infrabasal plates fused into a single pentagonal plate that is confined to the basal concavity; brachials wider than high (height to width ratio $\sim 1: 2.0-2.5$ ); proximal columnal circular not filling entire basal concavity. In contrast, $H$. geminatus aboral cup bowl to moderately conical in shape; ratio of 
336 aboral cup diameter versus crown height $\sim 1: 1.15-2.0$; , typically 2.0 times wider than high;

337 infrabasal plates fused into a single pentalobate plate that is confined to the basal concavity;

338 brachials wider than high (height to width ratio $\sim 1: 2.0-2.5$ ); proximal columnal circular not

339 filling entire basal concavity.

340 Similar to the Cupressocrinitidae described by Bohatý (2009b) and Bohatý and Ausich

341 (2021), Halocrinites from Poland have a variety of epizoans encrusting the outer surface of

342 crown plates. These include trepostome bryozoans encrusted on aboral cup and brachial plates. A

343 presumable microconchid that is attached to a radial plate, and a juvenile pelmatozoan holdfast is

344 attached to a different radial plate. These encrustations did not induce a recognizable response

345 from the crinoid host, so it is probable that these encrustations occurred after the death of the

346 crinoid and, thus, are episkeletozoans (see Taylor and Wilson, 2002).

Halocrinites schlotheimii Steininger, 1831

349

Figs. 3F1-F3, 5A1-A3, 5B1-B2, 5C1-C2, 53, 6A1, 6A2

350

351 Type

352 The type specimens for this taxon are not known.

353 Diagnosis

354 Halocrinites with bowl-shaped aboral cup with a ratio of aboral cup diameter versus aboral cup

355 height $\sim 1$ :1.15-2.0; aboral cup typically $\sim 2.0$ times wider than high; infrabasal plates fused into 
356 a single pentagonal plate that is confined to the basal concavity; brachials wider than high

357 (height to width ratio $\sim 1: 2.0-2.5$ ); proximal columnal circular not filling entire basal concavity.

358 Occurrence

359 In Poland, H. schlotheimii is from the Bukowa Góra Member (Emsian), Bukowa Góra quarry,

360 Holy Cross Mountains, Poland. Previously, this species has been described from the Eifelian and

361 Givetian of Australia, China, Germany, Poland, and Spain (Webster and Webster, 2019).

362

363

364

365

366

367

368

369

370

371

372

373

374

375

376

\section{Description}

Calyx medium sized. Aboral cup low to very low bowl shape in adults with height to maximum width ratio $0.44-0.66$ (Fig. $3 \mathrm{~F}$ ); perfect pentameral symmetry; deep, subpentalobate basal concavity occupies $62-66 \%$ of proximal aboral cup width (Fig. 5E). Plates gently convex; coarse multilaminar exoplacoid sculpturing preserved on only a few specimens.

Infrabasal circlet completely in basal concavity pentagonal. Infrabasal plates presumably five. Basal circlet $\sim 58-60 \%$ of aboral cup height, present on base and on vertical sides of aboral cup (Figs. 3D, 3F, 5A-5C). Five basal plates, equal in size, wider than high, smaller than radial plates. Radial circlet $40-42 \%$ of calyx height (Fig. 6A). Radial plates five, pentagonal, largest plates in aboral cup, height to width ratio $0.48-0.58$. Radial facets plenary, planate; radial facet topography not known. Posterior interray plates absent from aboral cup; anal sac, if present, unknown.

Arms five, atomous, brachials uniserial; V-shaped in cross section across width of brachial plate; incompletely known (preserved only through sixth primibrachial) (Fig. 6A). First primibrachial (articular plate, see Bohatý and Ausich, 2021), very low, full width of radial facet; 
377 subsequent brachials, flat sided, equal in width to distal edge of second primibrachials; height to

378 width ratio $\sim 0.65$.

379 Proximal column narrow, attachment to base of aboral cup circular, occupies slightly

380 more than one half of infrabasal circlet; remainder of column unknown.

\section{Measurements}

382 GIUS4-3693/Hschloth3: CrH, 33.0*; ACH, 7.5; ACmaxW, 11.3; $4^{\text {thPBH }}, 6.0 ; 4^{\text {thPBW }}$ 4.0.

383 GIUS4-3693/Hschloth4: ACH, 6.3; ACdistW, 14.0; BH, 6.3; BW, 6.5; RH, 4.3; RW, 8.9.

384 Remarks

385 Six specimens of $H$. schlotheimii are known from the Emsian of Poland (GIUS4-3693/Hschloth1 386 to GIUS4-3693/Hschloth6). In the collection of Polish specimens, small inidividuals tend to have 387 more pronounced convex basal plates that that nearly produce a central node.

388

389

390

391

392

393

394

395

396

Halocrinites geminatus (Bohatý, 2005)

Fig. 5D, 5H

\section{Type}

Holotype is SMF 75308 (see Bohatý, 2005).

\section{Diagnosis}

Halocrinites with aboral cup bowl to moderately conical in shape; ratio of aboral cup diameter versus aboral cup height $\sim 1: 1.15-2.0$; , typically 2.0 times wider than high; infrabasal plates 
397 fused into a single pentalobate plate that is confined to the basal concavity; brachials wider than

398 high (height to width ratio $\sim 1: 2.0-2.5$; proximal columnal circular not filling entire basal 399 concavity.

400 Occurrence

401 In Poland, H. geminatus is from the Bukowa Góra Member (Emsian), Bukowa Góra quarry, 402 Holy Cross Mountains. Previously, it was known from the Eifelian to early Givetian of Germany 403 (Webster and Webster, 2019).

\section{Description}

405 Calyx medium sized. Aboral cup very low bowl shape (Fig. 5D1), height to maximum width 406 ratio 0.43 ; perfect pentameral symmetry; shallow, subpentalobate basal concavity occupies $407 \sim 73 \%$ of proximal aboral cup width (Fig. 5D2). Plates gently convex with multilaminar 408 exoplacoid sculpturing (see Głuchowski, 1993a). concavity subtetragonal, entirely covered by proximal columnal. Infrabasal plates presumably

411 five. Basal circlet $\sim 56 \%$ of aboral cup height, present on base and on vertical sides of aboral cup.

412 Five basal plates, equal in size, wider than high, much smaller than radial plates. Radial circlet $413 \sim 44 \%$ of calyx height. Radial plates five, pentagonal, largest plates in aboral cup, height to width 414 ratio 0.60 . Radial facets plenary, planate; radial facet topography not known. Posterior interray 415 plates absent from aboral cup; anal sac, if present, unknown.

417 of brachial plate; incompletely known (preserved only through sixth primibrachial). First 418 primibrachial (articular plate, see Bohatý and Ausich, 2021), very low (height to width ratio 
419 0.16), full width of radial facet; subsequent brachials, flat sided, equal in width to distal edge of

420 second primibrachials; height to width ratio $\sim 1.2$.

421 Proximal column attachment to base of aboral cup wide, tetralobate, fills entire basal

422 concavity covering infrabasal plates; remainder of column unknown.

\section{Measurements}

424 GIUS4-3969/Hgem1: CrH, 41.0*; ACH, 9.0; ACmaxW, 21.0; ACproxW, 9.0; BConW, 6.5; BH,

425 7.6; BW, 7.25; RH, 5.9; RW, 12.4; $1^{\text {st } P b H, ~ 1.5 ; ~} 1^{\text {st } P b W, ~ 13.0 ; ~} 2^{\text {nd }} \mathrm{PbH}, 6.0 ; 2^{\text {nd }} P b p r o x W, 13.0$;

$426 \quad 2^{\text {ndPbdistW }, 10.0 ;} 3^{\text {rdPBH, }}$ 5.9.0; $3^{\text {rd }} \mathrm{PBW}, 5.0$.

427 Remarks

428 Bohatý (2005) illustrated individuals of $H$. geminatus with a wide variety of shapes. The

429 description above is for the Poland specimens that all have a very low bowl shape.

430

431

432

433

434

435

437

436 Bukowa Góra Member (Emsian), Bukowa Góra quarry, Holy Cross Mountains, southern Poland.

Figure 7 and 8 around here

Crinoidea Incertae Sedis

Figs. 5F, 5G, 6B-6D, 7A-7I, 8C, 8D

\section{Occurrence}

\section{Remarks}


438 A single brachial plate is identified as a flexible crinoid (GIUS4-3693/flexible; Fig. 7I). The

439 brachial plate is $\sim 4.0$ times deeper than high with, only the distal facet is visible and part of the

440 sides of the plate are visible that includes the aboral indentation where a patelloid process from

441 the distal adjoining brachial would reside. The brachial plate is as wide as deep. A crenulated

442 articular ridge is present along the abaxial portion of the facet, and the lateral sides of the facet

443 are crenulated. A narrow, shallow aboral groove is present along the adaxial margin of the facet.

444 Poorly preserved and unidentifiable remains of several additional taxa also occur in the

445 Bukowa Góra Member. In addition to the flexible crinoid and holdfasts mentioned below, others

446 include camerate crinoids (Fig. 5F, 5G) and various distinctive cladid crinoids (Fig. 6B-6D).

447 Distinctive columnals and pluricolumnals are also present (Fig. 7A, 8C, 8D). The pluricolumnals

448 illustrated in Fig. 8C undoubtedly belong to the Platycrinitidae and may be Platycrinites

449 minimalis (col.) Głuchowski, 1993a.

450

451

452

453

454

455

456

457 Solitary rugose coral and a presumable stromatoporoid specimens associated with the described

458 crinoids have small, discoid holdfasts cemented to their outer surface (Fig. 8A, 8B). These
Fig. 8A, 8B

\section{Occurrence}

Bukowa Góra Member (Emsian), Bukowa Góra quarry, Holy Cross Mountains, Poland.

\section{Remarks}

PeerJ reviewing PDF | (2021:12:68648:1:0:NEW 3 Jan 2022) 
459 holdfasts are subcircular in outline and some have a slightly digitate outer margin. In one

460 example, the holdfast articulation to the column was canted toward the long axis of a rugose

461 coral, suggesting the crinoid was encrusted to the coral when both were alive. Therefore, these

462 holdfasts should be considered epizoozoans (Taylor and Wilson, 2002). It is not possible to

463 speculate on the identity of the crown that was attached to these holdfasts, and the smaller

464 specimens may have been juveniles or from multiple radices of a single adult.

466 CONCLUDING REMARKS

467 The first Emsian crinoids described on the basis of aboral cups and crowns are reported here

468 from the Bukowa Góra Member in the Holy Cross Mountains of southern Poland. Named taxa

469 include Bactrocrinites sp., Codiacrinus sevastopuloi sp. nov., Halocrinites geminatus (Bohatý,

470 2005), Halocrinites schlotheimii Steininger, 1831. Taxa that can only be recognized as incertae

471 sedis include one flexible crinoid, as many as three camerate crinoids, as many as four additional

472 cladid crinoids, and a number of distinctive holdfasts, columnals, and pluricolumnals that cannot

473 be matched with the crown to which they were attached. Additional collecting in the Bukowa

474 Góra Member should yield remains of many crinoids.

Devonian strata in Poland (see Fig. 1). Further, species of Bactrocrinites, Codiacrinus, and

477 Halocrinites occur in other Devonian crinoid faunas from Germany and Spain (Webster and

478 Webster, 2019). 
481 are best represented by Emsian to Givetian crinoids from Germany and Spain (e.g., Bohatý, 482 2005, 2006, 2009b, Bohatý and Herbig, 2010; Hauser, 2001, 2002, 2007). Halocrinites has been 483 reported from Germany, Spain, Belgium, and Russia (Eifelian-Frasnian); wheras both 484 Codiacrinus and Bactrocrinites have longer ranges and are cosmopolitan in distribution. In 485 addition, to Western Europe, Codiacrinus is known from Gondwana terrane (northern Africa and 486 Australia). The oldest recognized species of Bactrocrinites is from the middle Silurian of North 487 America, and this genus is only known from North America and Europe. As known, 488 Bactrocrinites became extinct at the Givetian-Frasnian extinction and Bactrocrinites and 489 Halocrinites became extinct at the Frasnian-Famennian extinction.

\section{ACKNOWLEDGMENTS}

492

We thank Michał Stachacz, Kamil Moskowczenko, Damian Kuźma, Janusz Kucharski and Mateusz Syncerz for help during the field work. Jan Bohatý generously helped with identifications of taxa. Paweł Bącal is acknowledged for SEM imaging. We also thank Jan Bohatý and David L. Meyer, who provided critical reviews that significantly improved this paper. This project was supported by NCN Grant no. 2018/31/B/ST10/00387.

\section{REFERENCES}

Almela A, and Revilla J. 1950. Especies fósiles nuevas del Devoniano de León. Notas y Communicaciones del Instituto Geológico y Minero de España 20:45-60.

Bather, FA. 1890. British fossil crinoids. II. The classification of the Inadunata Fistulata (cont'd). Annals and Magazine of Natural History, ser. 6, 5:373-388. 
503 Bather FA. 1919. Cupressocrinus gibber n. sp. du Dévonien supérieur de Belgique. Bulletin de 504 la Société Belge de Géologie, de Paléontologie et l'Hydrologie 28:129-136.

505

506

507

508

509

510

511

512

513

514

515

516

517

518

519

520

521

522

523

524

525

Bohatý, J. 2005. Doppellagige Kronenplaten: Ein neues anatomisches Merkmal paläozoischer Crinoiden und Revision der Familie Cupressocrinitidae (Devon). Paläontologische Zeitschrift 79(2):201-225.

Bohatý, J. 2009a. First report of aboral cups of the crinoid family Parahexacrinidae from the Middle and Upper Devonian of the Eifel (Germany) and the Holy Cross Mountains (Poland). Paleontological Journal 43:1569-1577.

Bohatý, J. 2009b. Pre- and postmortem skeletal modifications of the Cupressocrinitidae (Crinoidea, Cladida). Journal of Paleontology 83:45-62.Bohatý J. 2006. Neue Cupressocrinitidae (Crinoidea) aus den mitteldevonischen Kalkmulden der Eifel (linksrheinisches Schiefergebirge, Deutschland). Senckenbergiana Lethaea 86(2):151189.

Bohatý J. 2011. Revision of the flexible crinoid genus Ammonicrinus and a new hypothesis on its life mode (Crinoidea, Flexibilia). Acta Palaeontologica Polonica 56(3):615-639.

Bohatý J, Ausich WI. 2021. Revision of two Devonian cupressocrinititids from the Schultze Collection (Museum of Comparative Zoology, Harvard University) and description of a new Halocrinites (Crinoidea, Eucladida). Journal of Paleontology, 17 pp. [doi: 10.1017/jpa.2021.65]

Bohatý, J, Herbig H-G. 2010. Middle Givetian echinoderms from the Schlade Valley (Rhenish Massif, Germany): habitats, taxonomy and ecostratigraphy. Paläontologische Zeitschrift $84: 365-386$. 
526 Dames W. 1868. Über die in der Umgebung Freiburgs in Nieder-Schlesien auftretenden

527

528

529

530

531

532

533

534

535

536

537

538

539

540

541

542

543

544

545

546

547

devonischen Ablagerungen. Zeitschrift der Deutschen Geologischen Gesellschaft 21:469-508.

Dubatolova YuA. 1964. Morskie lilii devona Kuzbassa. Akademiya Nauk SSSR, Sibirskoe Otdeleniye Trudy Instituta Geologii i Geofiziki, 153 pp.

Fijałkowska-Mader A, Malec J. 2011. Biostratigraphy of the Emsian to Eifelian in the Holy Cross Mountains (Poland). Geological Quarterly 55:109-138.

Fijałkowska-Mader A, Malec J, Tarnowska M, Turnau E. 1997. Stratygrafia dolnego dewonu w rejonie Bodzentyna - region łysogórski Gór Świętokrzyskich. Posiedzenia Naukowe Państwowego Instytutu Geologicznego 53:122-125.

Filipiak P. 2011. Palynology of the Lower and Middle Devonian deposits in southern and central Poland. Review of Palaeobotany and Palynology 166:213-252.

Follman O. 1887. Unterdevonische Crinoidea. Verhandlungen des Naturhistorischen Vereins der Preussischen Rheinlande, Westfalens, and des Regierungs-bezirks Osnabruck, 26 pp.

Głuchowski E. 1980. New taxa of Devonian and Carboniferous crinoid stem parts from Poland. Bulletin of the Polish Academy of Science 28:43-49.

Gluchowski E. 1981a. Stratigraphic significance of Paleozoic crinoid columnals from Poland. Zeszyty Naukowe AGH 7:89-110.

Głuchowski E. 1981b. Paleozoic crinoid columnals and pluricolumnals from Poland. Zeszyty Naukowe AGH 7:29-57.

Głuchowski E. 1981c. Człony łodyg liliowców z serii skalskiej (żywet) Gór Świętokrzyskich. Sprawozdanie z posiedzeń Komisji Nauk Geologicznych PAN 22:428-429. 
548 Gluchowski E. 1993a. Crinoid assemblages in the Polish Givetian and Frasnian. Acta

549 Palaeontologica Polonica 39:35-92.

550 Głuchowski E. 1993b. Upper Emsian crinoids from the Bukowa Góra quarry in the Klonów

551 Range, Holy Cross Mts. Prace Naukowe Uniwersyutetu Śląskiego, 1331, Geologia

$552 \quad 12 / 13: 159-174$.

553 Gluchowski E. 2002. Crinoids from the Famennian of the Holy Cross Mountains, Poland. Acta $554 \quad$ Palaeontologica Polonica 47:319-328.

555 Gluchowski E. 2003. Gromada Crinoidea Miller, 1821. In: Malinowska L. (ed.), Budowa 556 Geologiczna Polski. Atlas skamieniałości przewodnich i charakterystycznych. T. III. 557 Dewon. Państwowy Instytut Wydawniczy, Warszawa, 458-475.

558 Głuchowski E, Casier J-G, Olempska E. 2006. Crinoid and ostracod succession within the 559 Early-Middle Frasnian interval in the Wietrznia quarry, Holy Cross Mountains, Poland. $560 \quad$ Acta Palaeontologica Polonica 51:695-706.

561 Goldfuss GA. 1826-1844. Petrefacta Germaniae, tam ea, Quae in Museo Universitatis Regiae 562 Borussicae Fridericiae Wilhelmiae Rhenanea, serventur, quam alia quaecunque in Museis 563 Hoeninghusiano Muensteriano aliisque, extant, iconibus et descriptions illustrata. -Abbildungen und Beschreibungen der Petrefacten Deutschlands und der Angränzende 565 Länder, unter Mitwirkung des Hern Grafen Georg zu Münster, herausgegeben von August Goldfuss. v. 1 (1826-1833), Divisio prima. Zoophytorum reliquiae, p. 1-114; Divisio secunda. Radiariorum reliquiae, p. 115-221 [Echinodermata]; Divisio tertia. Annulatorium reliquiae, p. 222-242; v. 2 (1834-40), Divisio quarta. Molluscorum acephalicorum reliquiae. I. Bivalvia, p. 65-286; II. Brachiopoda, p. 287-303; III. (1841- 

Co.

572 Goldring, W. 1954. Devonian crinoids. new and old, II. New York State Museum Circular 37, $573 \quad 51 \mathrm{pp}$.

574

575

576

577

578

579

580

581

582

583

584

585

586

587

588

589

590

Gorzelak P, Gluchowski E, Salamon MA. 2014. Reassessing the improbability of a muscular crinoid stem. Scientific Reports 4:4069.

Gürich G. 1896. Das Paläozoicum im polnische Mittelgebirge. Verhandlungen der Russischkaiserlichen mineralogischen gesellschaft zu St. Petersburg 2, 168 pp.

Hauser J. 2001. Neubeschreibung mitteldevonischer Eifelcrinoiden aus der Sammlung Schultze (Museum of Comparative Zoology, The Agassiz Museum, Harvard University, Massachusetts, USA) nebst einer Zusammenstellung der Eifelcrinoiden (Holotypen) der Goldfuss-Sammlung. Published by author, Bonn, 86 pp.

Hauser J. 2002. Die Crinoiden der Frasnes-Stufe (Oberdevon) von Wallerheim/Loch (Prümer Mulde, Eifel) nebst einer Zusmmenstellung sämtlicher Melocriniten weltweit. Published by author, Bonn, 69 pp.

Hauser J. 2007. Die Crinoidenwelt der Eifel vor 350.000.000 Jahren-Neue Crinoiden aus dem Mitteldevon der Eifel, Tiel 2. Published by author, Bonn, 83 pp.

Jaekel O. 1895. Beiträge zur Kenntniss der palaeozoischen Crinoiden Deutschlands. Paläontologisches Abhandlungen 7, (n.f. 3), p. 1-116.

Jaekel O. 1918. Phylogenie und System der Pelmatozoen. Paläeontologische Zeitschrift 3:1128. 
591 Jell PA. 1999. Silurian and Devonian crinoids from central Victoria. Memoirs of the Queensland 592 Museum 43:114 pp.

593

594

595

596

597

598

599

600

601

602

603

604

605

606

607

608

609

610

Jell PA, Holloway DJ. 1983. Devonian and ?Late Silurian palaeontology of the Winneke Reservoir site, Christman Hills, Victoria. Proceedings of the Royal Society of Victoria $95: 1-21$.

Jell PA, Jell JS. 1999. Crinoids, a blastoid and a cyclocystoid from the Upper Devonian reef complex of the Canning Basin, Western Australia. Memoirs of the Queensland Museum 43: 201-236.

König CDE. 1825. Icones Fossilium Sectiles. London, 4 pp.

Kongiel R. 1958. Nowy gatunek Ammonicrinus i jego występowanie w Polsce. Prace Muzeum Ziemi 2:31-40.

LeMenn J. 1985. Les crinoides du Dévonien inférieur et moyen du massif Armoricain. Mëmoires de la Société Géologique et Minéralogique de Bretagne 30, 268 pp.

LeMenn J. 1997. Crinoïdes devoniens d'Afrique du nord. revision systematique et affinites paleobiogeographiques. Annales de la Société Géologique du Nord, 2nd ser 5:129-139.

Lobanowski H. 1971. The Lower Devonian in the western part of the Klonów belt (Holy Cross Mts). Part 1. Upper Emsian. Acta Geologica Polonica 21:629-686.

Lobanowski H. 1981. Bukowa Góra quarry: Lower Devonian sandstones. In: Żakowa H. (ed.), Przewodnik 53 Zjazdu Polskiego Towarzystwa Geologicznego w Kielcach, Wydawnictwa Geologiczne; Warszawa, 249-255. 
611 Malec J. 2005. Lithostratigraphy of the Lower and Middle Devonian boundary interval in the

612 Łysogóry Region of the Holy Cross Mts (Poland). Biuletyn Państwowego Instytutu 613 Geologicznego 415:5-28.

614 Marynowski L, Salamon MA, Narkiewicz M. 2002. Thermal maturity and depositional 615 environments of organic matter in the post-Variscan succession on the Holy Cross 616 Mountains. Geological Quarterly 46:25-36.

617

618

Miller JS. 1821. A natural history of the Crinoidea, or lily-shaped animals; with observations on the genera, Asteria, Euryale, Comatula and Marsupites. Bristol, C. Frost, 150 pp.

Moore RC, Jeffords RM. 1968. Classification and nomenclature of fossil crinoids based on studies of dissociated parts of their columns. The University of Kansas Paleontological Contributions 46:1-86.

Moore RC, Laudon LR. 1943. Evolution and classification of Paleozoic crinoids. Geological Society of America Special Paper 46, 151 pp.

Piotrowski A. 1977. Genus Ammonicrinus (Crinoidea) from the Middle Devonian of the Holy Cross Mountains, Poland. Acta Palaeontologica Polonica 22:205-218.

Prokop RJ. 1973. Elicrinus n. gen. from the Lower Devonian of Bohemia (Crinoidea). Véstnik Ustrédniho Ustavu Geologickeho 48(4):221-224.

Reed FRC. 1908. The Devonian faunas of the Northern Shan states. India Geological Survey, Memoirs 2(5). 157 pp.

Roemer, CF. 1844. Das Rheinische Übergangsgebirge. Eine palaeontologisch-geognostische Darstellung. Hannover, Hahn, 96 pp. 
632 Roemer, CF. 1850. Über Stephanocrinus, eine fossile Crinoiden-Gattung aus der Familie der 633 Cystideen. Wiegmanns Archiv für Naturgeschichte, Jahrgang 16:365-375.

634

635

636

637

638

639

640

641

642

643

644

645

646

647

648

649

650

651

652

653

Roemer CF. 1852-54. Erste Periode, Kohlen-Gebirge. In Lethaea Geognostica, H. G. Bronn, 1851-1856, 3rd edit. Stuttgart, E. Schweizerbart, 2, 788 pp.

Salamon MA, Gerrienne P, Steemans P, Gorzelak P, Filipiak P, Le Hérissé A, Paris F, Cascales-Miñana B, Brachaniec T, Misz-Kennan M, Niedźwiedzki R, Trela W. 2018. Putative Late Ordovician land plants. New Phytologist DOI: doi.org/10.1111/nph.15091.

Sandberger G, Sandberger F. 1850-1856. Die Versteinerungen des rheinischen Schichtensystems in Nassau. Wiesbaden, Kreidel and Niedner, 564 pp.

Schmidt WE. 1934. Die Crinoideen des Rheinischen Devons, I. Teil; Die Crinoideen des Hunsrückschiefers. Abhandlung der Preussischen Geologischen Landesanstalt 163, 149 pp.

Schmidt WE. 1941. Die Crinoiden des Rheinischen Devons II. Teil. A. Nachtrag zu: Die Crinoiden des Hunsrückschiefers; B. Die Crinoideen des Unterdevons bis zur cultrijugatus-Zone (mit Ausschluß des Hunsrückschiefers). Abhandlungen der Preußischen Geologischen Landesanstalt 182, 253 pp.

Schmidt WE. 1942. Die Crinoideen des Rheinischen Devons, II. Teil; A. Nachtrag zu Die Crinoideen des Hunsrückschiefers; B. Die Crinoideen des Unterdevon bis zur Cultrijugatus -Zone (mit Ausschluss des Hunsrückschiefers). Abhandlungen der Reichstelle für Bodenforschung, n. s., 182, 253 pp.

Sobolev D. 1909. Sredniy devon kelecko-sandomirskoho krjaza. Materialy dla geologii Rossiji 24:41-536. 
654 Schultze LJT. 1866. Monographie der Echinodermen des Eifler Kalkes. Vienna, Carl 655 Gerold's Sohn, 118 pp.

656 Springer F and Slocom AW. 1906. Hypsocrinus, a new genus of crinoids from the Devonian. 657 Field Columbia Museum Publication, 114, Geology Series 2(9): 267-271,

658 Steininger J. 1831. Bemerkungen über die Versteinerungen, welche in dem Uebergangs659 Kalkgebirge der Eifel gefunden werden. Eine Beilage zum Gymnasial-Programm zu $660 \quad$ Trier, Trier, $44 \mathrm{pp}$.

661

662

663

664

665

666

667

668

669

670

671

672

673

Steininger J. 1849. Die Versteinerungen des Uebergangs-Gebirges der Eifel. Jahresbericht über den Schul-Cursus 1848/49 an dem Gymnasium zu Trier, 21-22.

Strimple, HL. 1952. Some new species of crinoids from the Henryhouse Formation of Oklahoma. Journal of the Washington Academy of Science 42:75-79.

Stukalina, GA. 1965. Novye vidji Hexacrinites tsentralnogo Kazakhstana [New species of Hexacrinites from central Kazakhstan]. Ezhegodnik Vsesoyuznogo Paleontologische Obshchestva, v. 17, p. 188-195 (In Russian).

Szulczewski M. 1995. Depositional evolution of the Holy Cross Mts. (Poland) in the Devonian and Carboniferous - a review. Geological Quarterly 39471:159-174.

Szulczewski M, Porębski S. 2008. Stop 1 - Bukowa Góra, Lower Devonian. In: Pieńkowski G. and Uchman A. (eds), Ichnological Sites of Poland - the Holy Cross Mountains and the Carpathian Flysch: The Second International Congress on Ichnology, The Pre-Congress and Post-Congress Field Trip Guide Book, Cracow, 18-37. 
674 Taylor PD, Wilson MA. 2002. A new terminology for marine organisms inhabiting hard 675 substrates. PALAIOS 17:522-525.

676

677

678

679

680

681

682

683

684

685

686

687

688

689

690

691

692

693

Wachsmuth C, Springer F. 1880-1886. Revision of the Palaeocrinoidea. Proceedings of the Academy of Natural Sciences of Philadelphia Pt. I. The families Ichthyocrinidae and Cyathocrinidae (1880), p. 226-378, (separate repaged p. 1-153). Pt. II. Family Sphaeroidocrinidae, with the sub-families Platycrinidae, Rhodocrinidae, and Actinocrinidae (1881), p. 177-411 (separate repaged, p. 1-237). Pt. III, Sec. 1. Discussion of the classification and relations of the brachiate crinoids, and conclusion of the generic descriptions (1885), p. 225-364 (separate repaged, 1-138). Pt. III, Sec. 2. Discussion of the classification and relations of the brachiate crinoids, and conclusion of the generic descriptions (1886), p. 64-226 (separate repaged to continue with section 1, 139-302).

Webster GD, Webster DW. 2019. Bibliography and index of Paleozoic crinoids, coronoids, and hemistreptocrinids, 1758-2012. http://crinoids.azurewebsites.net/ (accessed September 2021).

Webster GD, Becker RT, Maples CG. 2005. Biostratigraphy, paleoecology, and taxonomy of Devonian (Emsian and Famennian) crinoids from southeastern Morocco. Journal of Paleontology 79: 1052-1071.

Wójcik K. 2015. The uppermost Emsian and lower Eifelian in the Kielce Region of the Holy Cross Mts. Part I: Lithostratigraphy. Acta Geologica Polonica 65:141-179. 
694 Wright DF. 2017. Bayesian estimation of fossil phylogenies and the evolution of early to middle 695 Paleozoic crinoids (Echinodermata). Journal of Paleontology 91:799-814, [doi:

696 10.1017/jpa.2016.141].

697

698

699

700

701

702

703

704

705

706

707

708

709

710

711

712

713

714

Wright DF, Ausich WI, Cole SR, Peter ME, Rhenberg EC. 2017. Phylogenetic taxonomy and classification of the Crinoidea (Echinodermata). Journal of Paleontology 91:829-846.

Yeltyschewa RS, Dubalotova YA. 1961. Morskie lilii V kn. Biostratigrafiia paleozoia SayanoAltaiskoi gornoi oblasti, Srednii paleozoi, t. II [Crinoids. In Biostratigraphy of the Paleozoic of the Sayano Altai mountainous country, middle Paleozoic, v. II]. Moscow, Izdatel'stvo Nauka, Trudy, pt. 20:294-296, 552-560. (In Russian)

Yeltyschewa RS. and Sisova EN. 1973. Anthinocrinidae-Novoe Semeistvo Srednepaleozoiskikh Morskikh Lilii V kn. Voprosy Stratifrafii i Tektoniki Vostochnogo Kazakhstana [Anthinocrinidae New Family of Middle Paleozoic Marine Lily. In Aleksandrova, M. I., ed, Questions on the Stratigraphy and Tectonics of East Kazakhstan]. Trudy Vsesoyuznogo Ordena Lenina Nauchno-Issledovatelskogo Geologicheskogo Instituta, n. s. 160:86-99 (In Russian)

Zeiler F, Wirtgen PW. 1855. Bemerkungen über die Petreefacten der älteren devonischen Gebirge am Rheine, insbesondere über die Echinodermen in der Umgegend von Coblenz und in dem Eifeler Kalke vorkommenden Arten. Verhandlungen des Naturhistorisch Vereins der Preussischen Rheinlands und Westfalen 12:79-85.

Zeuschner L. 1867. Devonische Formation im Sandomirer-Chenciner Gebirge. Neues Jahrbuch für Mineralogie, Geologie und Paläontologie 67:478-508. 
715 Zeuschner L. 1869. Geognostische Beschreibung der mittleren devonischen Schichten zwischen 716 Grzegorzowice und Skały-Zagaje, bei Nowa Słupia. Zeitschrift der Deutschen Geologischen Gesellschaft 21:263-274.

718

719

720

721

722

723

724

725

726

727

728

729

730

731

732

733

734

735

Zittel KA, von. 1895. Grundzüge der Palaeontologie (Palaeozoologie), 1st edit. R. Oldenbourg, München, $971 \mathrm{pp}$.

\section{Captions:}

Figure 1 Stratigraphic ranges of crinoid taxa recorded in Devonian of Poland. Data compiled after: Dames (1868), Zeuschner (1867, 1869), Gürich (1896), Sobolev (1909), Kongiel (1958), Piotrowski (1977), Głuchowski (1980, 1981a-c, 1993, 2002, 2003), and Hauser (2002).

Figure 2 (A) The map of Poland with the Holy Cross Mountains area marked as grey rectangle. B. The lithostratigraphical scheme of Middle and Upper Devonian in the Bukowa Góra Quarry. Compiled after Marynowski et al. (2002), Malec (2005), Szulczewski \& Porębski (2008), Wójcik (2015), and Salamon et al. (2018).

Figure 3 (A1-A4) Codiacrinus sevastopuloi sp. nov. GIUS 4-3696/Codiacrinus1, holotype; (A1) lateral view of aboral cup; (A2) basal view of aboral cup, note basal concavity bordered by ridge; (A3), oral view of aboral cup; (A4), lateral view of aboral cup. (B1-B3) Codiacrinus sevastopuloi sp. nov. GIUS 4-3696/Codiacrinus2. paratype; (B1) lateral view of aboral cup; (B2) basal view of aboral cup; (B3) oral view of aboral cup. (C) lateral view of an incomplete and 
736

737

738

739

740

741

742

743

744

745

746

747

748

749

750

751

752

753

754

755

756 Figure 6 (A1-A2) Halocrinites schlotheimii; (A1) lateral view of partial crown, aboral cup plate 757 boundaries distinct; (A2) basal view of a moderately compressed aboral cup. GIUS 4-

compressed specimen of Codiacrinus sevastopuloi sp. nov. GIUS 4-3696/Codiacrinus3. (D1-D2)

compressed specimen of Halocrinites sp. GIUS 4-3696/Hsp; (D1) lateral view of aboral cup with plate boundaries visible; (D2) basal view of cup. (E) Bactrocrinites sp. GIUS 4-

3696/Bactrocrinites1; lateral view of incomplete aboral cup, note small radial plates and large basal plates. (F1-F3) compressed aboral cup of Halocrinites schlotheimii. GIUS 4-

3696/Hschloth1 (F1) oblique basal view; (F2, F3) lateral views. All specimens are from Bukowa Góra Member (Emsian), Bukowa Góra quarry, Holy Cross Mountains, southern Poland. Scale bar equals $10 \mathrm{~mm}$.

Figure 4. Plate drawing of the posterior of Bactrocrinites sp.

Figure 5 (A1-A3, B1-B2, C1-C2) Halocrinites schlotheimii. GIUS 4-3696/Hschloth2, 5 and 4 respectively; (A1, B1, C1) lateral views of aboral cup; (A2, B2, C2) basal views of aboral cup; (A3) oral view of aboral cup. (D, H) Halocrinites geminatus. GIUS 4-3696/Hgem2 and 1 respectively; (D1) lateral view of aboral cup; (D2) basal view of aboral cup. (E) Halocrinites with good exoplacoid sculpturing preserved; GIUS 4-3696/Hschloth6. (F, G) Crinoidea indeterminate (presumably remains of a camerate crinoid). GIUS 4-3696/indet1 and 2 respectively. All specimens are from Bukowa Góra Member (Emsian), Bukowa Góra quarry, Holy Cross Mountains, southern Poland. Scale bar equals $10 \mathrm{~mm}$. 
758 3696/Hschloth3. (B-D) Crinoidea indeterminate; GIUS 4-3696/indet3, 4 and 5 respectively; (B,

759 C) partial arms of an unknown cladid crinoids; (D) in upper left of specimen a pentalobate

760 column presumably infrabasal plates attached; probably an unknown cladid). All specimens are

761 from Bukowa Góra Member (Emsian), Bukowa Góra quarry, Holy Cross Mountains, southern

762 Poland. Scale bar equals $10 \mathrm{~mm}$.

763

764

Figure 7 (A-H) crinoid pluricolumnals. GIUS 4-3696/indet6-13. (A, B) pluricolumnal with

765

numerous nodes around the periphery of each columnal; (C), set of pluricolumnals; (D)

766

pluricolumnal with nodes and perhaps some spines around the periphery of each columnal; (E)

767

numerous pluricolumnals of a column that lacks nodes; (F) lateral view of three-columnal

768

pluricolumnal with a few nodes around the periphery of columnals that are offset in position

769

from one columnal to the next; $(\mathrm{G})$ columnal facet with a narrow peripheral lumen and a narrow,

raised perilumen; (H) columnal with a wide lumen and a narrow, raised perilumen: (I) Flexible

771

crinoid brachial. GIUS 4-3696/flexible; note crenulate sides and on the upper margin a notch to

772

hold a patelloid process from the next highest columnal. All specimens are from Bukowa Góra

773

Member (Emsian), Bukowa Góra quarry, Holy Cross Mountains, southern Poland. All scale bar

774 equals $10 \mathrm{~mm}$ but in case of flexible crinoid brachial it is $1 \mathrm{~mm}$.

Figure 8 (A, B) crinoid holdfast on stromatoporoids. GIUS 4-3696/holdfast1 and 2 respectively.

777 (C) crinoid pluricolumnal presumably from the dististele with broken radices; (D) pluricolumnal with elliptical columnals, presumably from a member of the Platycrinitidae; GIUS 4- 
779 3696/indet14 and 15 respectively. All specimens are from Bukowa Góra Member (Emsian),

780 Bukowa Góra quarry, Holy Cross Mountains, southern Poland. Scale bar equals $10 \mathrm{~mm}$. 


\section{Figure 1}

Figure1. Stratigraphic ranges of crinoid taxa recorded in Devonian of Poland.

Data compiled after: Dames (1868), Zeuschner (1867, 1869), Gürich (1896), Sobolev (1909),

Kongiel (1958), Piotrowski (1977), Głuchowski (1980, 1981a-c, 1993, 2002, 2003), and Hauser (2002). 


\begin{tabular}{|c|c|c|c|c|c|c|c|}
\hline Lochkovian & Pragian & Emsian & Eifelian & Givetian & Frasnian & Famenn. & Crinoid taxa \\
\hline & & & & & & & Kotanocrinus cf. balaensis (col.) \\
\hline & & & & & & & Poteriocrinites? morlieresensis \\
\hline & & & & & & & Formosocrinus cf. formosus (col.) \\
\hline & & & & & & & Acanthocrinus sp. (col.) \\
\hline & & & & & & & Marettocrinus subbiconcavus (col.) \\
\hline & & & & & & & \\
\hline & & & & & & & $\begin{array}{l}\text { Procupressocrinites gracilis } \\
\text { Mediocrinus microgrumosus (col.) }\end{array}$ \\
\hline & & & & & & & \\
\hline & & & & & & & $\begin{array}{l}\text { Aspachstanocrinus actullobus (col.) } \\
\text { Asperocrinus brevispinosus (col.) }\end{array}$ \\
\hline & & & & & & & Ricebocrinus kulagaiensis (col.) \\
\hline & & & & & & & Ammonicrinus sulcatus (col.) \\
\hline & & & & & & & Eocamptocrinus fragilis (col.) \\
\hline & & & & & & & Gilbertsocrinus vetulus (col.) \\
\hline & & & & & & & Myelodactylus canaliculatus (col.) \\
\hline & & & & & & & Pentagonostipes petaloides (col.) \\
\hline & & & & & & & Platycrinites minimalis (col.) \\
\hline & & & & & & & Noctoicrinus? varius (col.) \\
\hline & & & & & & & Marettocrinus angustannulus (col.) \\
\hline & & & & & & & $\begin{array}{l}\text { Halocrinites schlotheimi } \\
\text { Praerocrinus polonicus }(\mathrm{col})\end{array}$ \\
\hline & & & & & & & \\
\hline & & & & & & & Stenocrinus degratus (col.) \\
\hline & & & & & & & Tantalocrinus scutellus (col.) \\
\hline & & & & & & & Tjeecrinus crassijugatus (col.) \\
\hline & & & & & & & Schyschcatocrinus creber (col.) \\
\hline & & & & & & & Kazachstanocrinus tenuis (col.) \\
\hline & & & & & & & Stenocrinus raricostatus (col.) \\
\hline & & & & & & & Marettocrinus kartzevae (col.) \\
\hline & & & & & & & Ammonicrinus kongieli (col.) \\
\hline & & & & & & & Amurocrinus imatschensis (col.) \\
\hline & & & & & & & Haplocrinites minor \\
\hline & & & & & & & Laudonomphalus pinguicostatus (col.) \\
\hline & & & & & & & Haplocrinites aremoricanus \\
\hline & & & & & & & Anthinocrinus brevicostatus (col.) \\
\hline & & & & & & & Anthinocrinus primaevus (col.) \\
\hline & & & & & & & Halocrinites inflatus \\
\hline & & & & & & & Ononicrinus gracilis (col.) \\
\hline & & & & & & & Urushicrinus perbellus (col.) \\
\hline & & & & & & & Ricebocrinus parvus (col.) \\
\hline & & & & & & & Tjeecrinus simplex (col.) \\
\hline & & & & & & & Schyschcatocrinus multiformis (col.) \\
\hline & & & & & & & Haplocrinites sp. \\
\hline & & & & & & & Schyschcatocrinus delicatus (col.) \\
\hline & & & & & & & Wenjukowiocrinus wenjukowi (col.) \\
\hline & & & & & & & Caleocrinus bicostatus (col.) \\
\hline & & & & & & & Glyphidocrinus infimus (col.) \\
\hline & & & & & & & Caleocrinus kielcensis (col.) \\
\hline & & & & & & & Melocrinites cf. hieroglyphicus \\
\hline & & & & & & & Melocrinites cf. gibbosus \\
\hline & & & & & & & Exaesidiscus compositus (col.) \\
\hline & & & & & & & Haplocrinites gluchowskii \\
\hline & & & & & & & Tjeecrinus insectus (col.) \\
\hline & & & & & & & Cosmocrinus polonicus (col.) \\
\hline
\end{tabular}


Figure 2

Figure 2. (A) The map of Poland with the Holy Cross Mountains area marked as grey rectangle. (B) The lithostratigraphical scheme of Middle and Upper Devonian in the Bukowa Góra Quarry.

Compiled after Marynowski et al. (2002), Malec (2005), Szulczewski \& Porębski (2008), Wójcik (2015), and Salamon et al. (2018). 

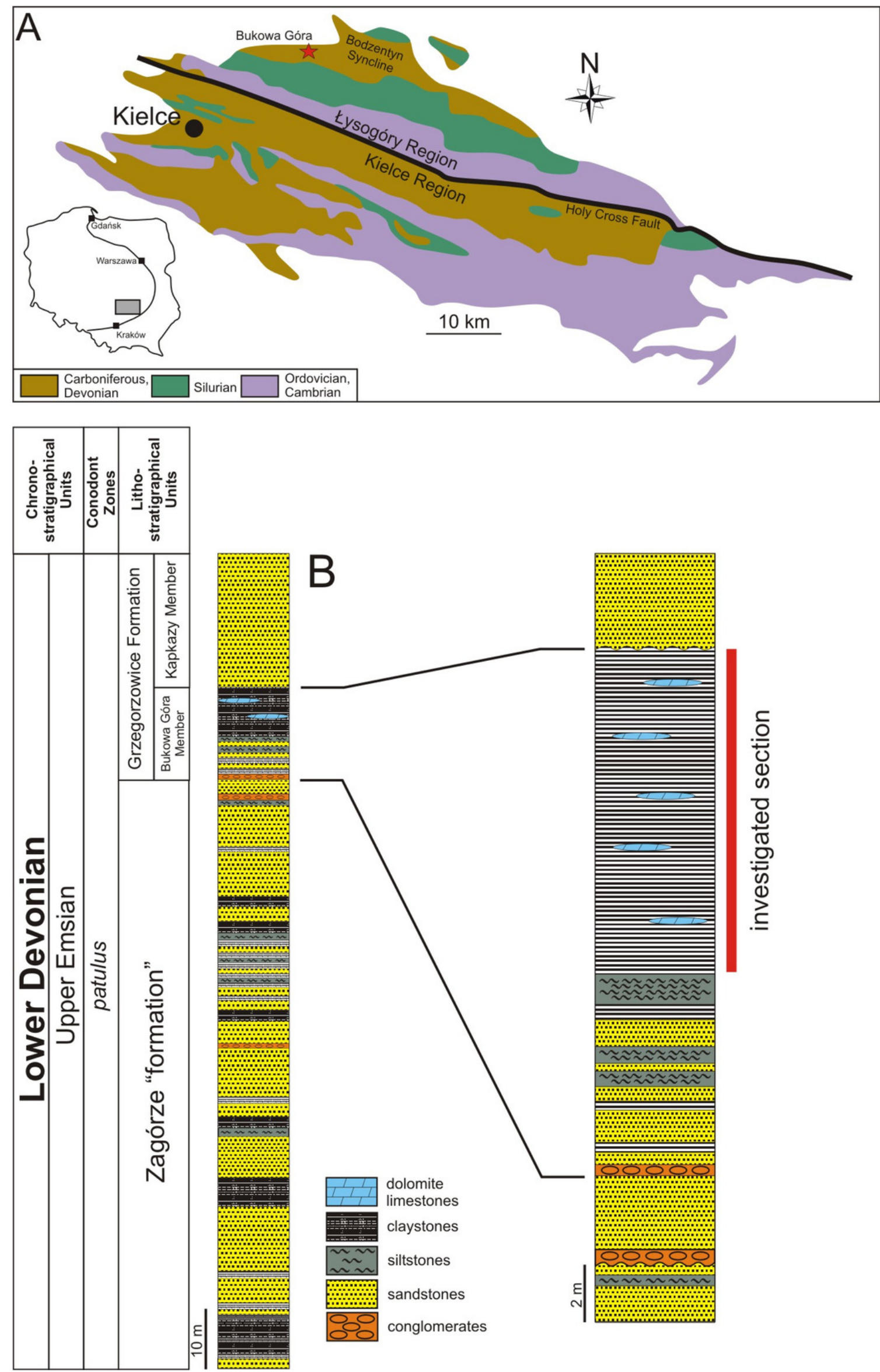

PeerJ reviewing PDF | (2021:12:68648:1:0:NEW 3 Jan 2022) 
Figure 3

Figure 3. (A1-A4) Codiacrinus sevastopuloi sp. nov. GIUS 4-3696/Codiacrinus1, holotype; (A1) lateral view of aboral cup; (A2) basal view of aboral cup, note basal concavity bordered by ridge; (A3), oral view of aboral cup; (A4), lateral

All specimens are from Bukowa Góra Member (Emsian), Bukowa Góra quarry, Holy Cross Mountains, southern Poland. Scale bar equals $10 \mathrm{~mm}$. 

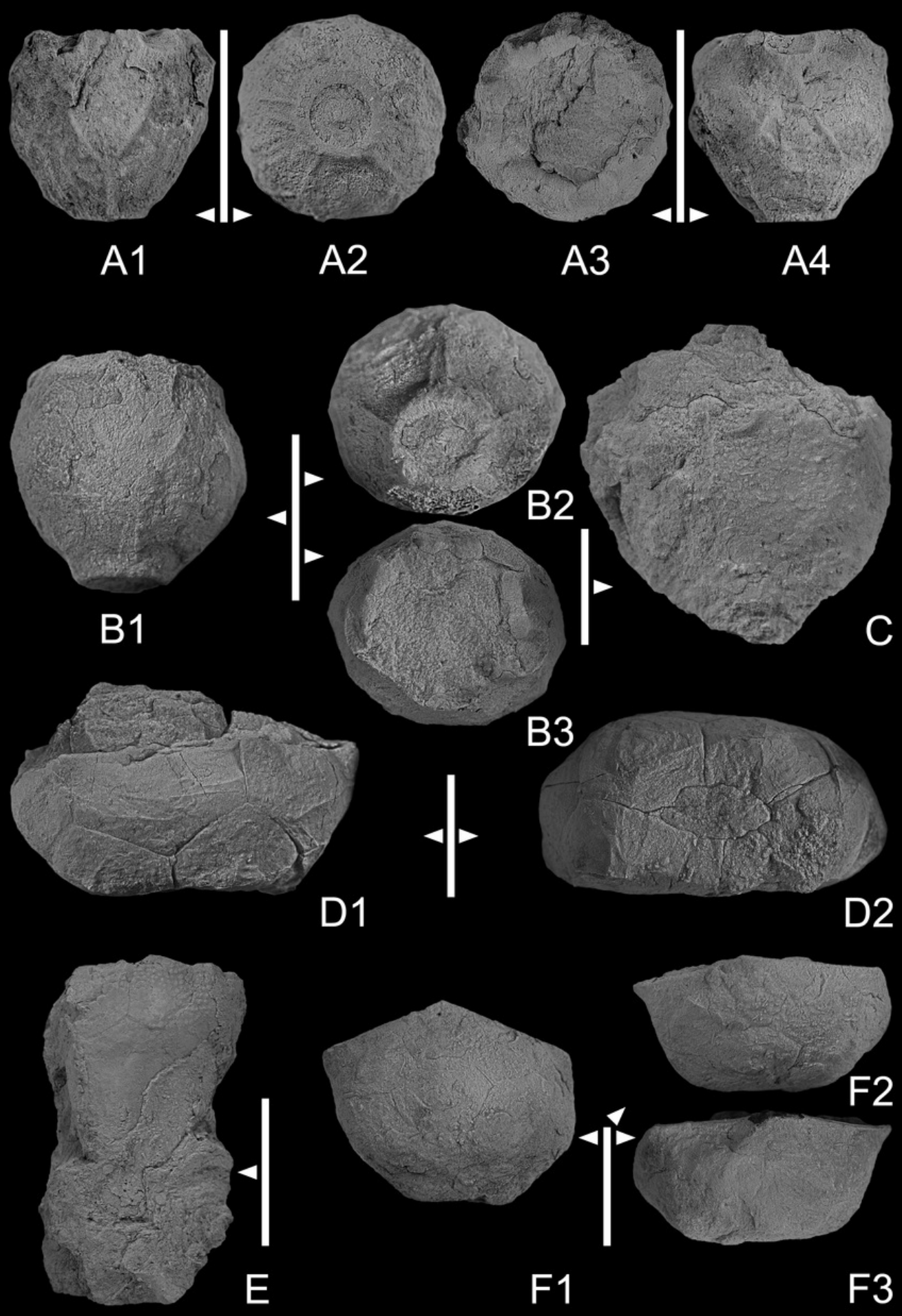
Figure 4

Figure 4. Plate drawing of the posterior of Bactrocrinites sp. 


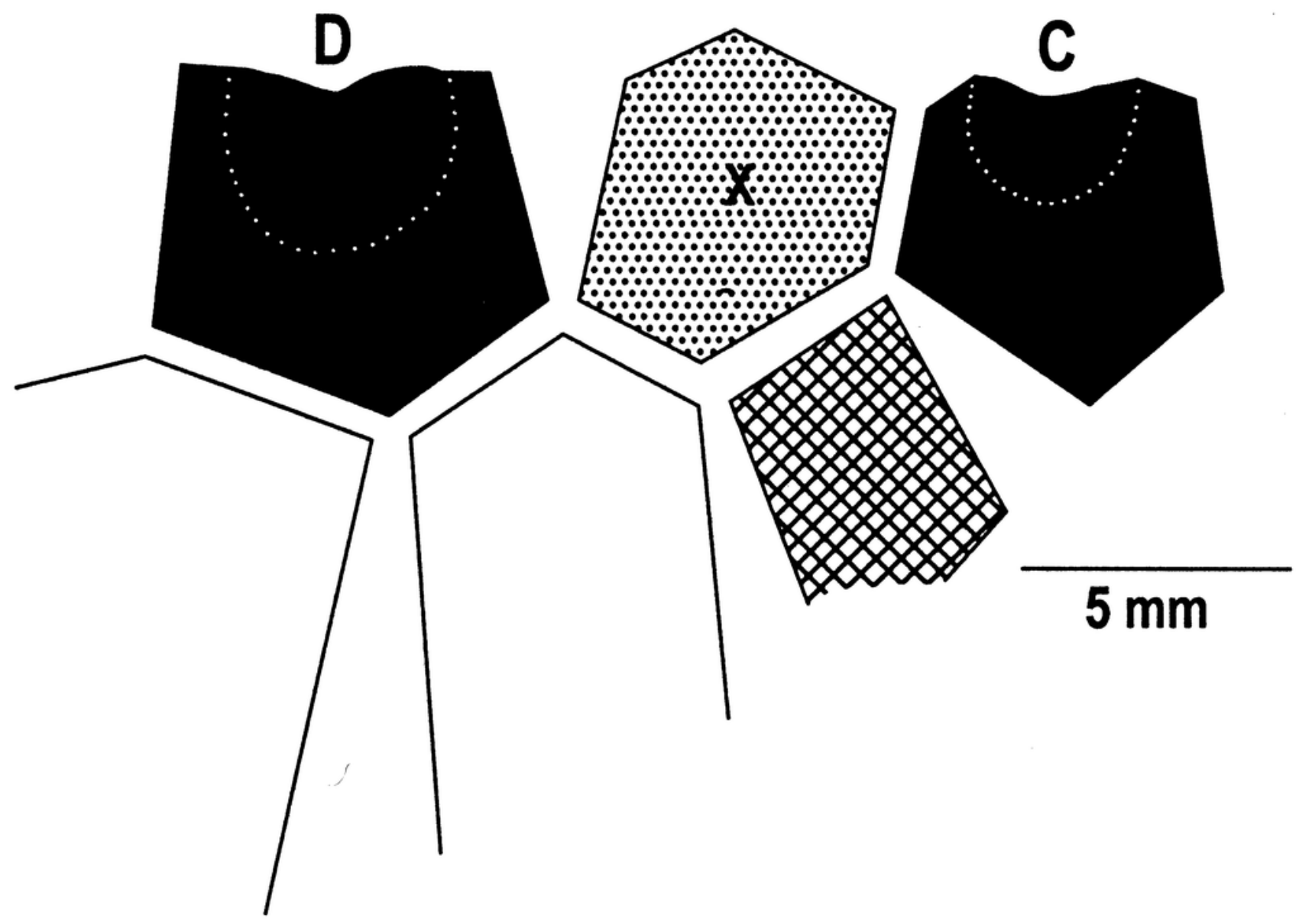


Figure 5

Figure 5. (A1-A3, B1-B2, C1-C2) Halocrinites schlotheimii. GIUS 4-3696/Hschloth2, 5 and 4 respectively; $(A 1, B 1, C 1)$ lateral views of aboral cup; $(A 2, B 2, C 2)$ basal views of aboral cup; (A3) oral view of aboral cup. (D, H) [i]Halocrinites gem

All specimens are from Bukowa Góra Member (Emsian), Bukowa Góra quarry, Holy Cross Mountains, southern Poland. Scale bar equals $10 \mathrm{~mm}$. 


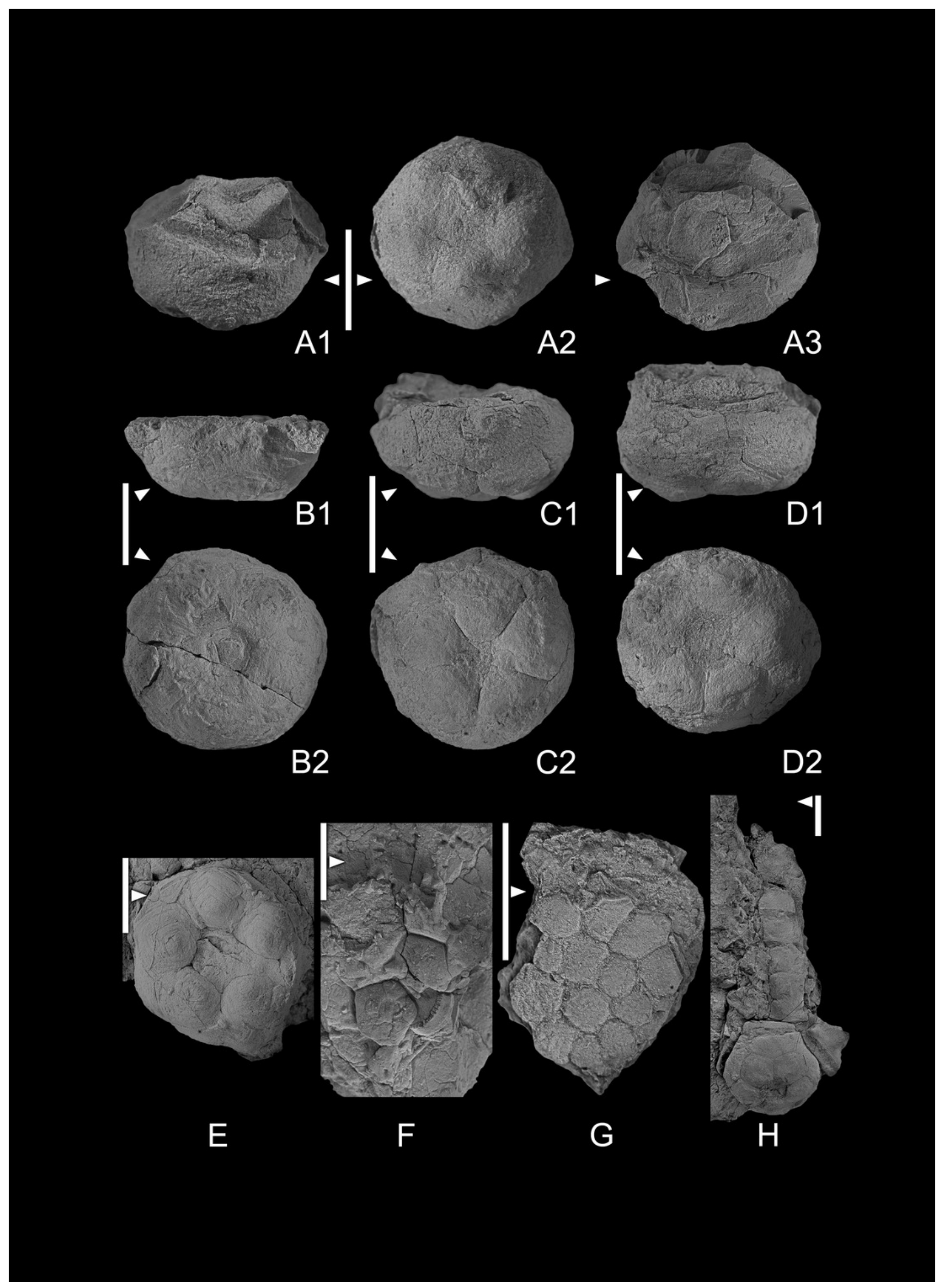


Figure 6

Figure 6. (A1-A2) Halocrinites schlotheimii; (A1) lateral view of partial crown, aboral cup plate boundaries distinct; (A2) basal view of a moderately compressed aboral cup. GIUS 4-3696/Hschloth3. (B-D) Crinoidea indeterminate; GIUS 4-3

All specimens are from Bukowa Góra Member (Emsian), Bukowa Góra quarry, Holy Cross Mountains, southern Poland. Scale bar equals $10 \mathrm{~mm}$. 

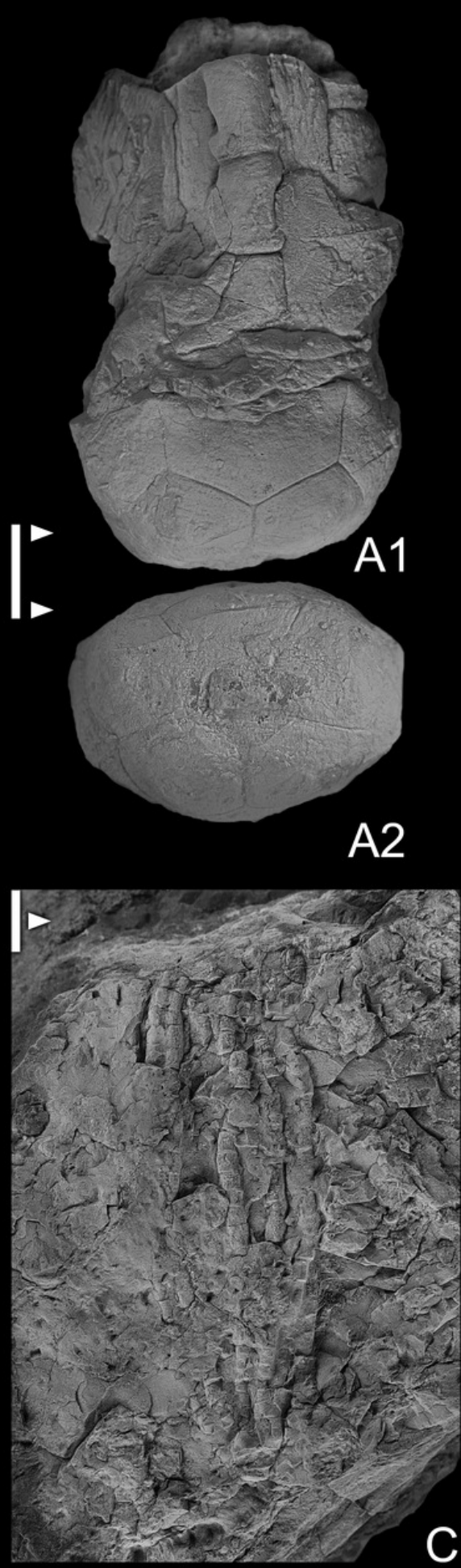
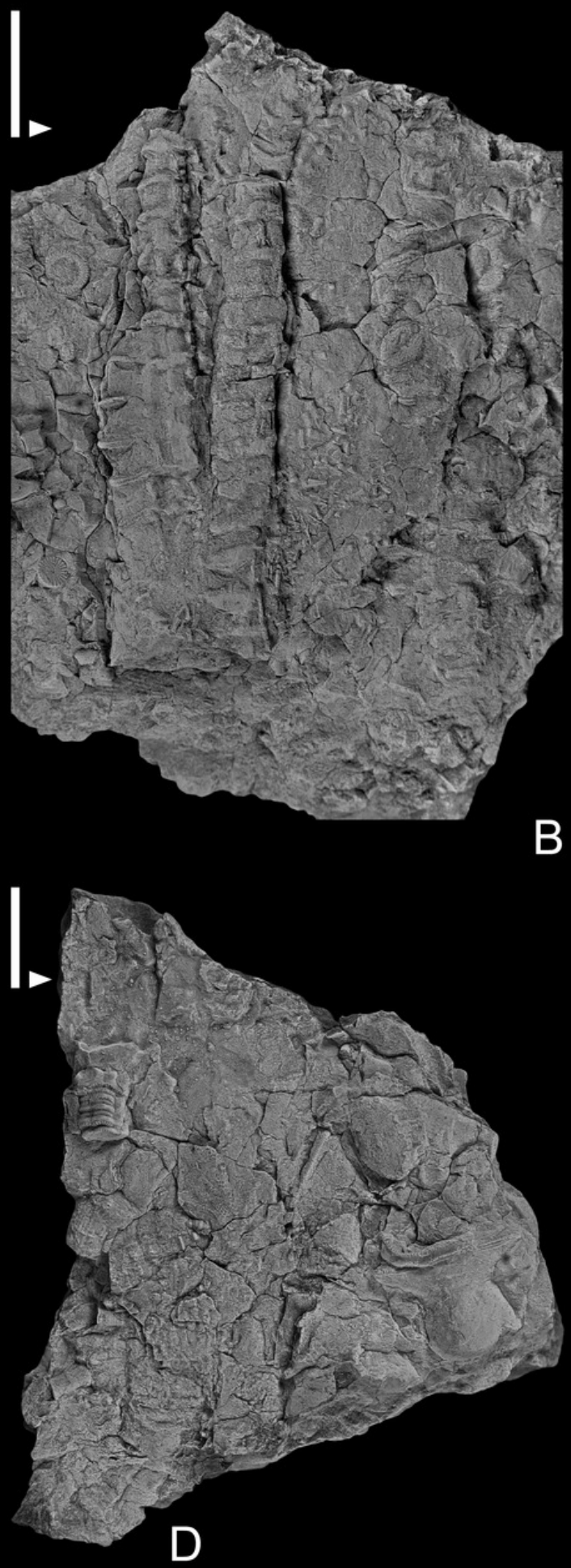


\section{Figure 7}

Figure 7. (A-H) crinoid pluricolumnals. GIUS 4-3696/indet6-13. (A, B) pluricolumnal with numerous nodes around the periphery of each columnal; (C), set of pluricolumnals; (D) pluricolumnal with nodes and perhaps some spines around the periphery of

All specimens are from Bukowa Góra Member (Emsian), Bukowa Góra quarry, Holy Cross Mountains, southern Poland. All scale bar equals $10 \mathrm{~mm}$ but in case of flexible crinoid brachial it is $1 \mathrm{~mm}$. 


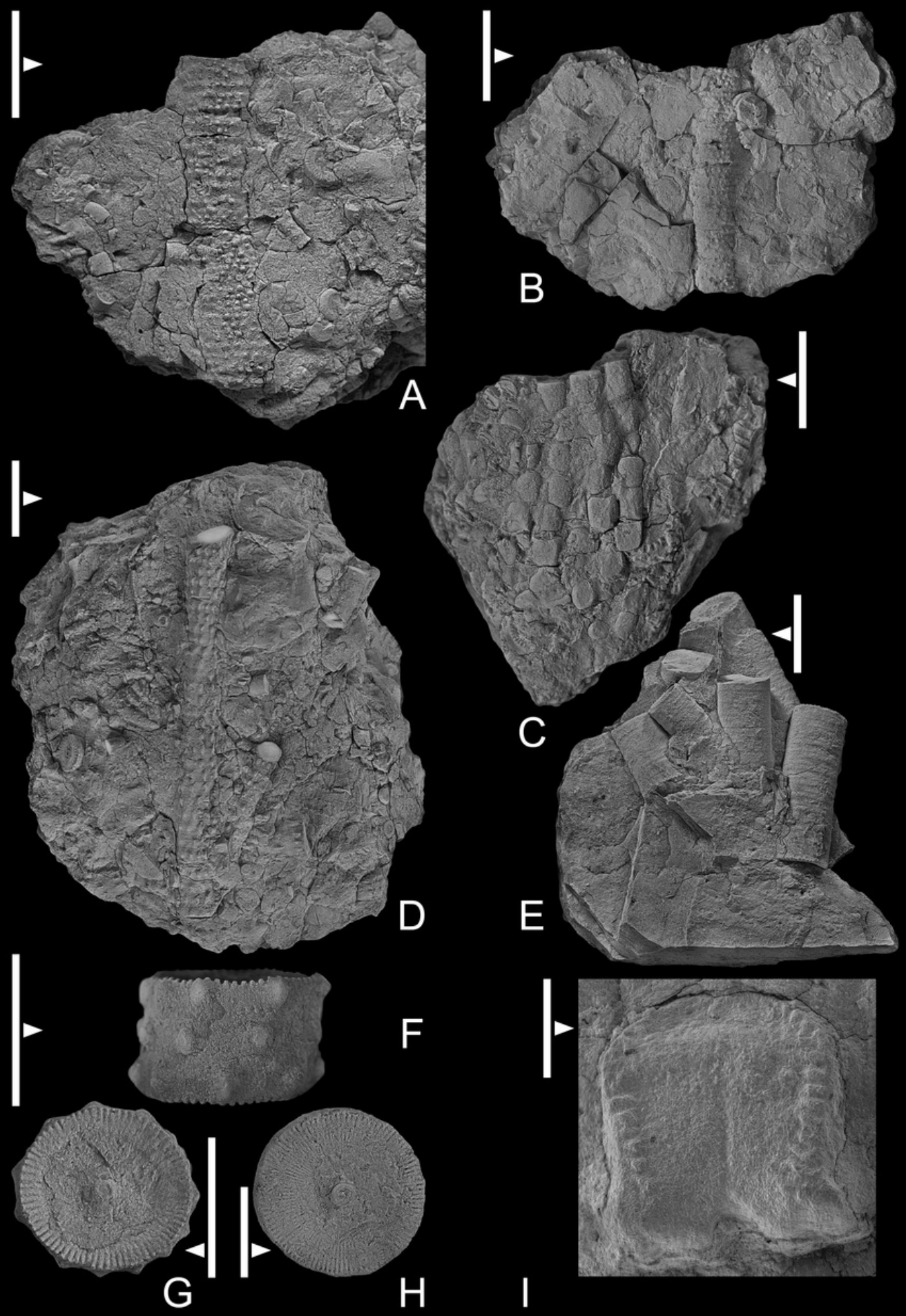




\section{Figure 8}

Figure 8. (A, B) crinoid holdfast on stromatoporoids. GIUS 4-3696/holdfast1 and 2 respectively. (C) crinoid pluricolumnal presumably from the dististele with broken radices; (D) pluricolumnal with elliptical columnals, presumably from a member of $t$

All specimens are from Bukowa Góra Member (Emsian), Bukowa Góra quarry, Holy Cross Mountains, southern Poland. Scale bar equals $10 \mathrm{~mm}$. 

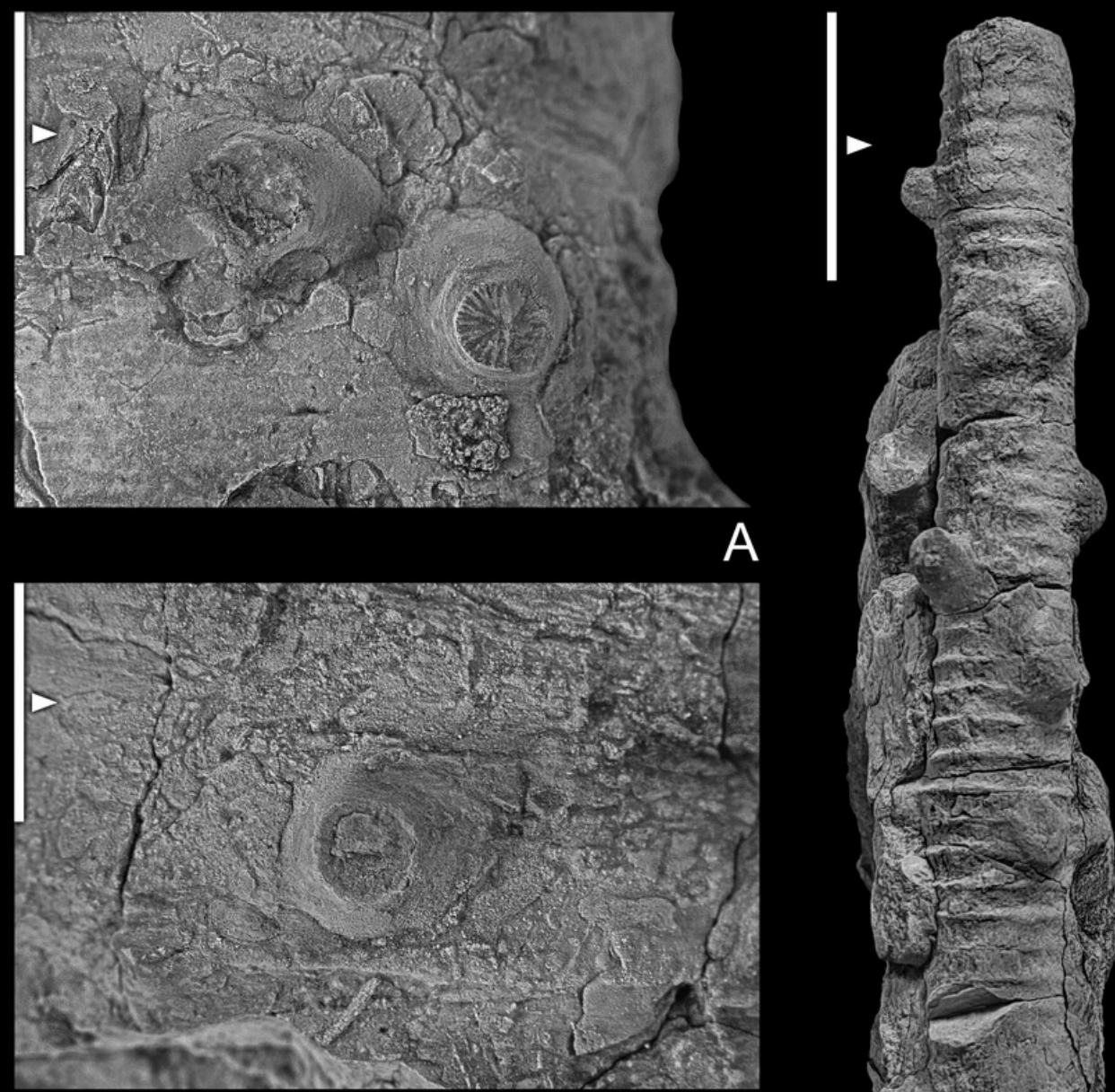

B
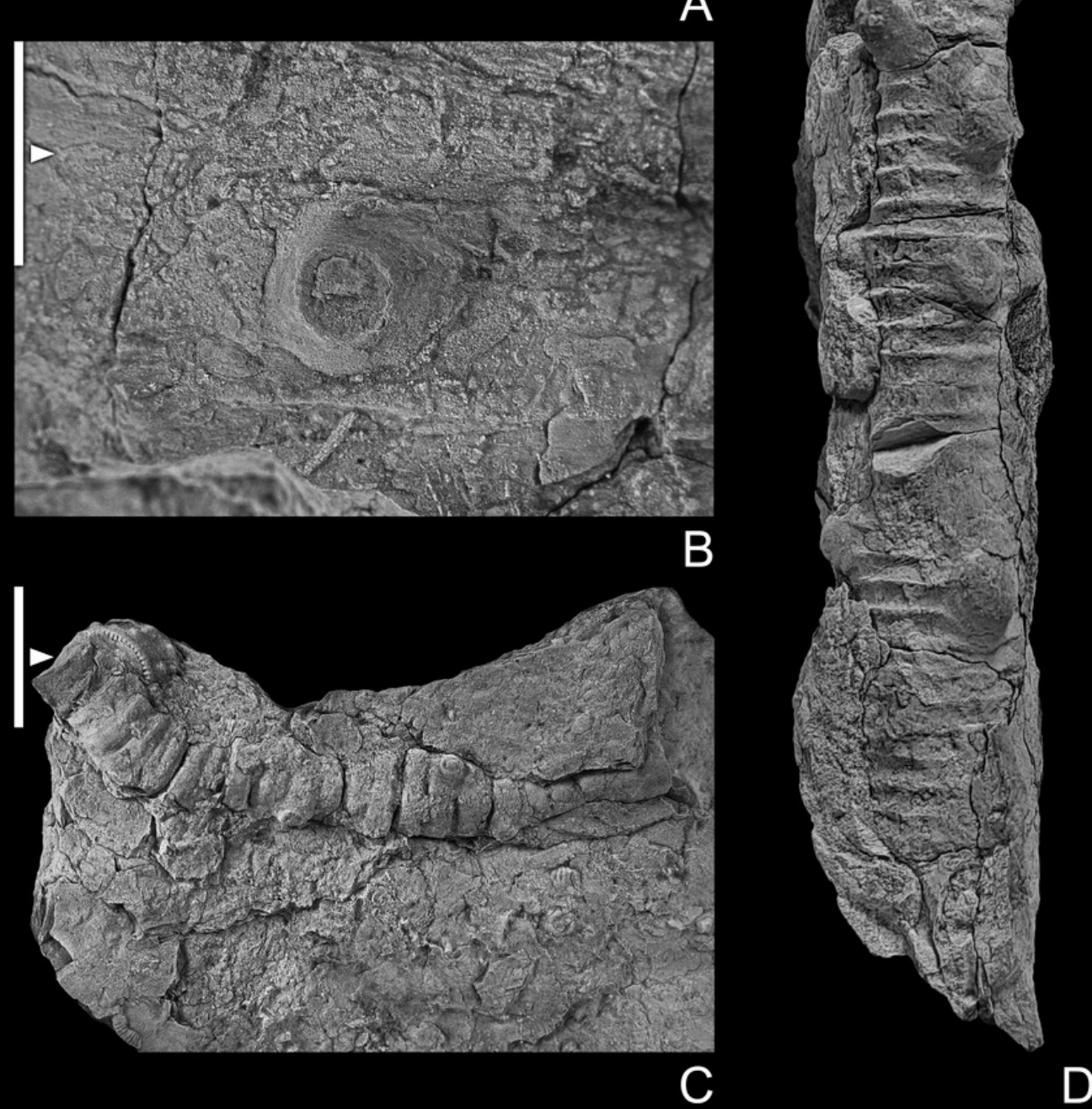